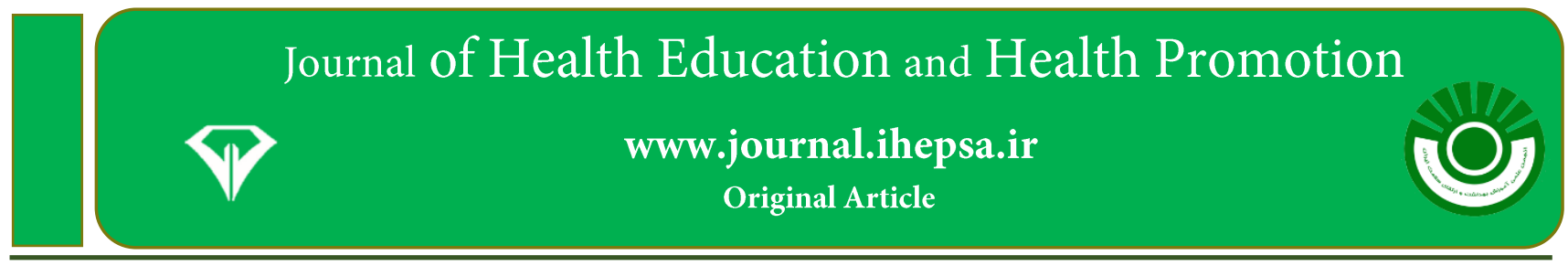

\title{
View of Mental and Social Health of Refugee Women in the Third Millennium: The big National and International Challenge
}

\author{
Katayoun Jahangiri ${ }^{1}$, Shahnaz Tabatabei $^{2}, \underline{\text { Shiva Yousefian }}^{1}$
}

1. Dept. of Health in Disasters and Emergencies, School of Health, Safety and Environment, Shahid Beheshti University of Medical Sciences, Tehran, Iran

2. Dept. of Ergonomics School of Health, Safety and Environment, Shahid Beheshti University of Medical Sciences, Tehran, Iran

\section{Article Information}

\section{Article History:}

Received: 2017/02/18

Accepted: 2018/02/10

Available online: 2018/06/17

\section{IJHEHP 2018; 6(2): 134-146}

DOI: 10.30699/acadpub.ijhehp.6.2.134

\section{Corresponding Author:}

\section{Shiva Yousefian}

Dept. of Health in Disasters and Emergencies, School of Health, Safety and Environment, Shahid Beheshti University of Medical Sciences, Tehran, Iran Tel: 021-81452630

Email: shyousefian@sbmu.ac.ir

Use your device to scan and read the article online

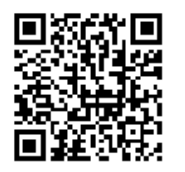

\section{Abstract}

Background and Objective: Hundreds of millions of people affected from natural and man-made disasters in the world and about 80 percent of these people are women and children. Women and girls for various social, economic, cultural and health reasons are more vulnerable in times of disaster. This study aimed to investigate the impact of displacement on women's mental and social health.

Methods: This research is an analytical review of articles that was studied by searching articles in Iranian databases: SID, Magiran and Irandoc, and foreign databases: Web of Science, Scopus, PubMed, Google Scholar and by using of keywords such as: Psychological vulnerability, mental health, women in disasters, refugees, disasters and their possible combinations.

Results: According to the different needs of women in disaster such as deprivation in access to health services, prenatal care, specific health concerns, forcing in nutrition of children, the risk of sexual violence, sexually transmitted diseases, emotional and economic dependence and difficulty in social interactions, the vulnerability of this group in terms of displacement can be classified in five dimensions (1) health, (2) self-care, (3) livelihoods, (4) social capital and (5) social support.

Conclusion: In disasters, cultural barriers, physical health problems, communication barriers, language and social and economic problems are the most important struggles of women that lead to mental disorders. Therefore, programs should be designed related to prevention, preparedness and response based on women's needs and challenges with them participating; it is important that sufficient political and economic support from governments and involved organizations in these programs will be allocated.

KeyWords: Mental Health, Social Health, Women, Refugees

Copyright @ 2018 Journal of Health Education and Health Promotion. All rights reserved.

How to cite this article:

Jahangiri K, Yousefian S, Tabatabaee S. View of Mental and Social Health of Refugee Women in the Third Millennium: The big National and International Challenge . Iran J Health Educ Health Promot. $2018 ; 6$ (2): 134-146

Jahangiri, K., Yousefian, S., Tabatabaee, S. (2018).View of Mental and Social Health of Refugee Women in the Third Millennium: The big National and International Challenge . Iranian Journal of Health Education and Health Promotion; 6 (2): 134-146 


\section{سيماى سلامت روانى و اجتماعى زنان آواره در هزاره سوم: جالش بزركى

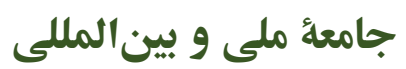 \\ كتا يون جهانغيرى'، شهناز طباطبايى'، شيوا يوسفيان'}

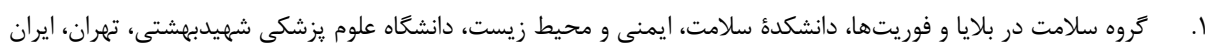

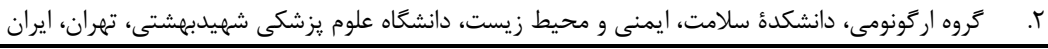

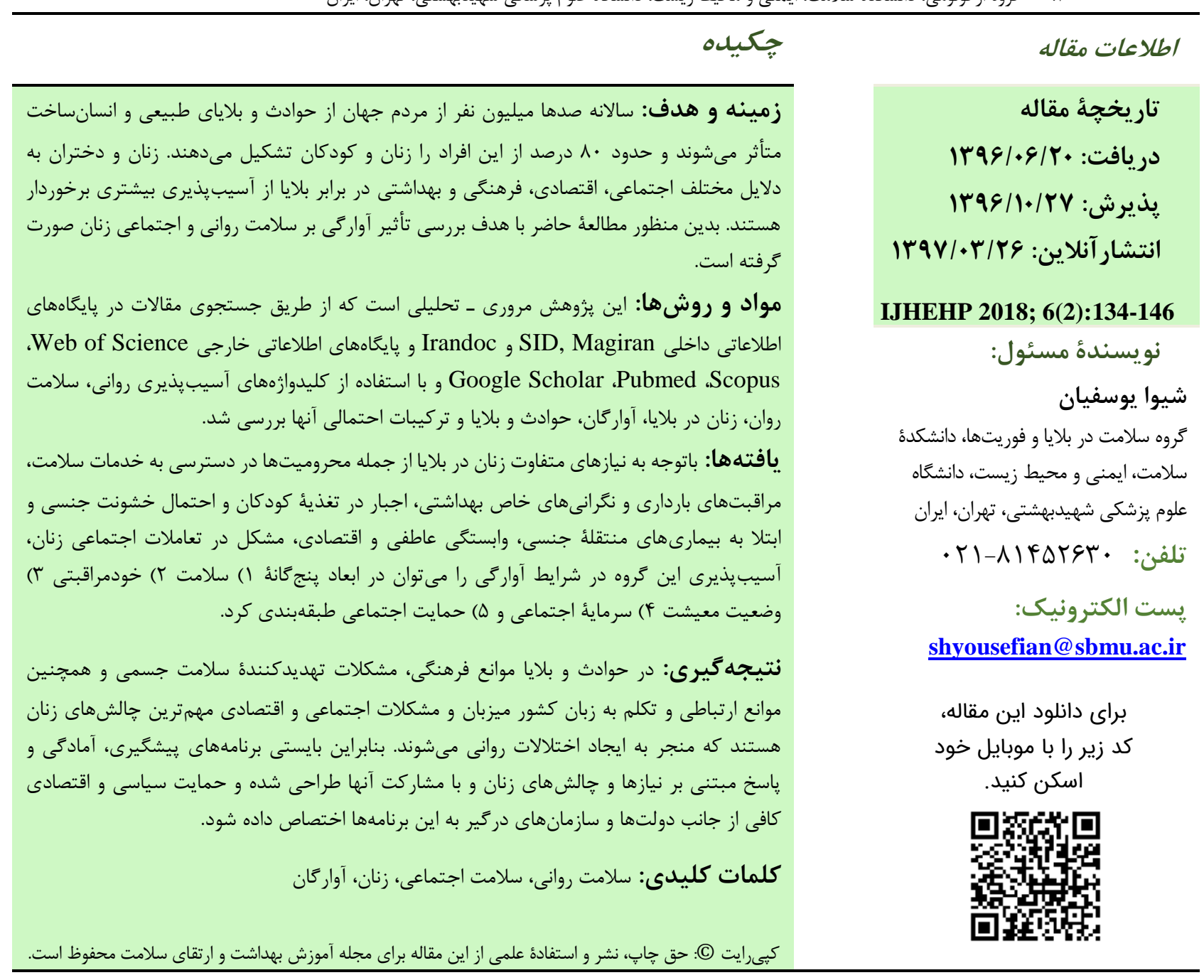

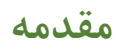

و ويرانىها را بهجا كذاشته و بخش بزركى از منابع و

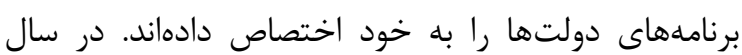

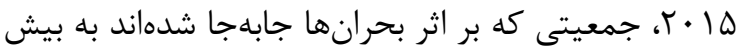

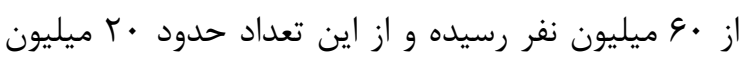
نفر مجبور به مهاجرت به ساير كشورها شدند كه اين آمار

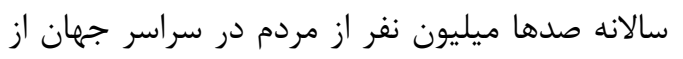

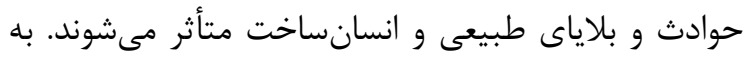

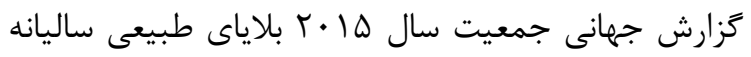

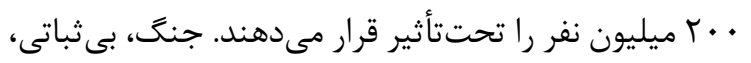
بيمارى هاى مسرى و حوادث طبيعى حجم عظيمى از مصائب 
اين گَروه از افراد ضرورى است. لذا در اين مطالعه سعى بر

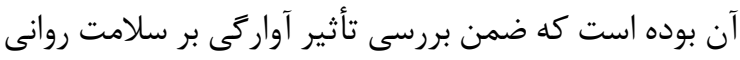
و اجتماعى زنان، در خصوص اقداماتى كه لازم است در در برد

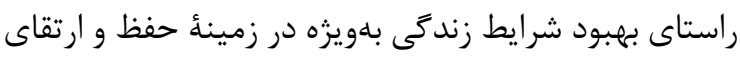
سلامت آنها از سوى نظام سلامت صورت كيرد، بحث شود.

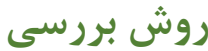

مطالعُ حاضر از نوع مرورى ـ تحليلى است كه در سال

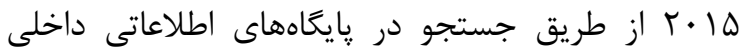

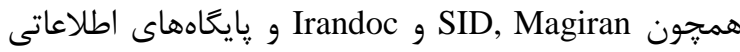
خارجى Woogle ،pubmed ، Webus of Science ، Scholar سلامت روان، زنان در بلايا، آواركان، حوادث و بلايا و

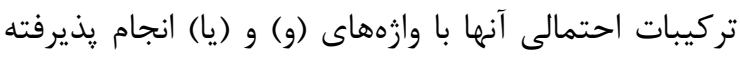

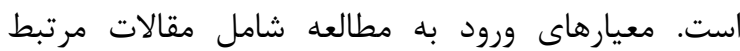
جابֶ

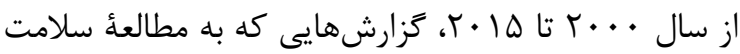

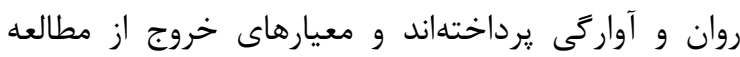

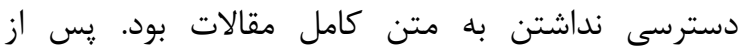

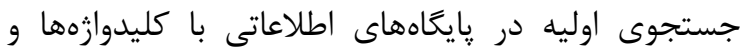

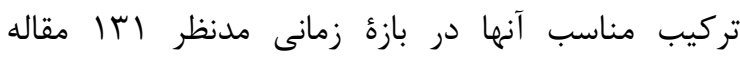
جمع آورى شد. يس از بررسى عنوان و خارج كردن مقالات

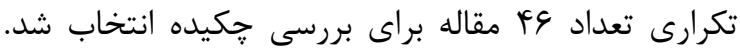

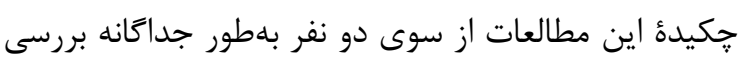
و در صورت نداشتن توافق، به نفر سوم ارجاع داده شد. يس از بررسى نويسندكان و با توجه به امكان دسترسى به

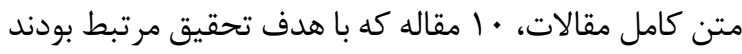

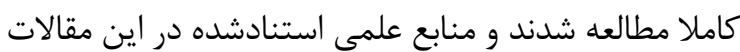
منتخب نيز بررسى و يك مقاله به ليست نهايى اضافه شد. در نهايت / 1 مقاله براى بررسى در اين مطالعه انتخاب شدند.

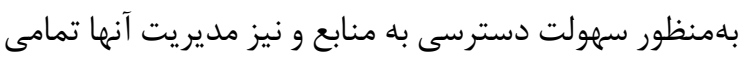
منابع استخراجشده از بانكهاى اطلاعاتى در نرمافزار

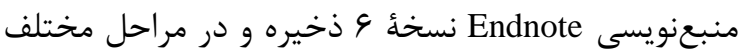
غر بالكرى استفاده شد

يافته ها

با توجه به بررسى متون انجامشده، يافتههاى بهدستآمده در دو بخش "آواركى و اختلالات روانى" و و

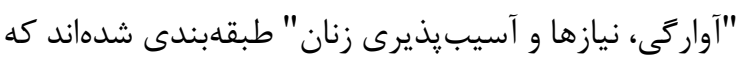

$$
\text { در ادامه بر رسى مىشوند. }
$$

بيش از تعداد آوار كان جنگ جهانى دوم و بى سابقه بوده است

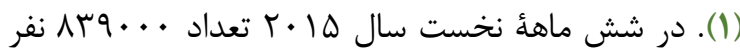
يعنى بهطور متوسط .44 نفر در هر روز ناتزير به ترك

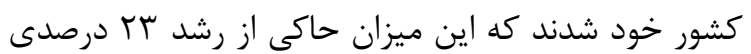
نسبت به سالهاى اخير بوده است. با در نظر كرفتن اين آن ردان موضوع كه \&1 درصد آواركان در كشورهاى درحال توسعه

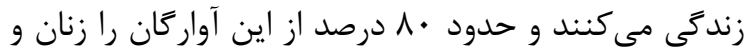
كودكان تشكيل مى دهند (ז). در اين ميان زنان و دختران

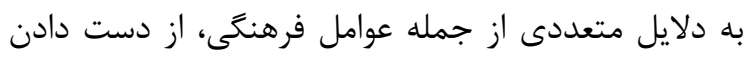

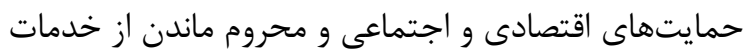
بهداشتى و درمانى مرتبط با سلامت بارورى بهطور

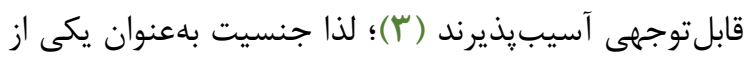
جنبههاى كليدى آسيبريذيرى در برابر حوادث و بلايا قابل

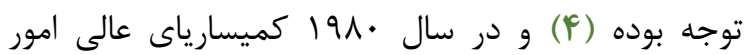
يناهندًان سازمان ملل (UNHCR) زنان آواره را بهعنوان

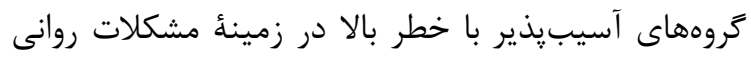

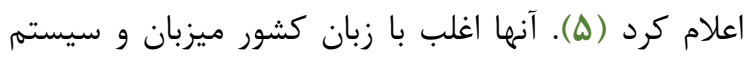

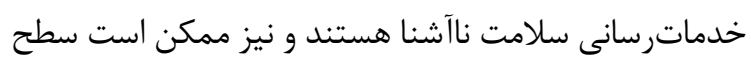
بالايى از استرس را بهدليل بىثباتى يا اعمال خشونت و وانئ

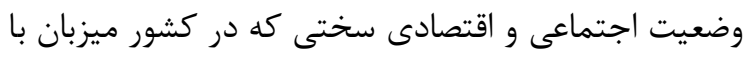

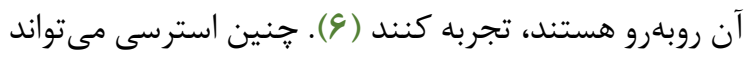

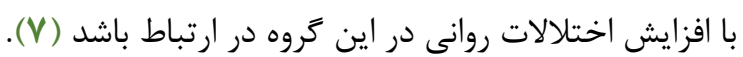
بر اهميت توجه به سلامت زنان در اهداف توسعة هزارة

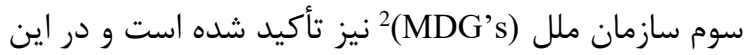
سند كه يك خارجوب بينالمللى براى سنجش مئ ميزان

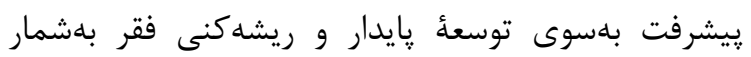
مىرود، سه هدف ارتقاى برابرى جنسيتى و توانمند ساختن

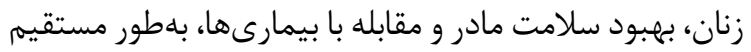

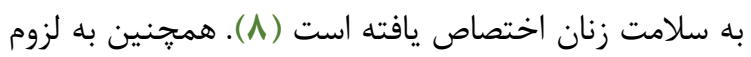

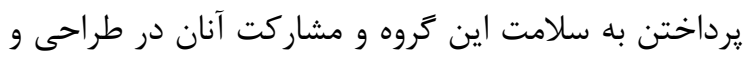
اجراى سياستها و برنامههاى كاهش خطر حوادث و بلايا و وران

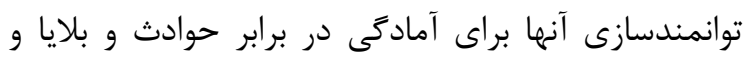

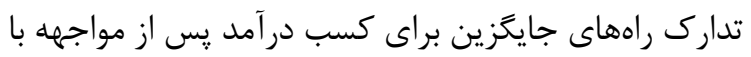
اين شرايط، در سند سنداى و برنامؤ استراتزيك شش سالئ درائ سازمان جهانى بهداشت نيز توجه شده است (9). در راستاى

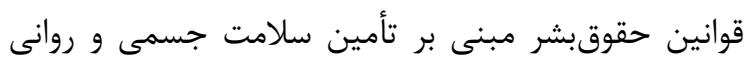

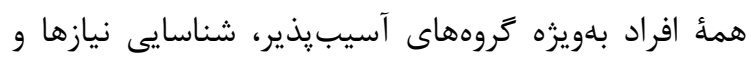

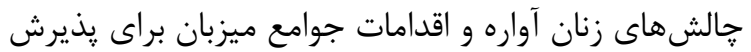




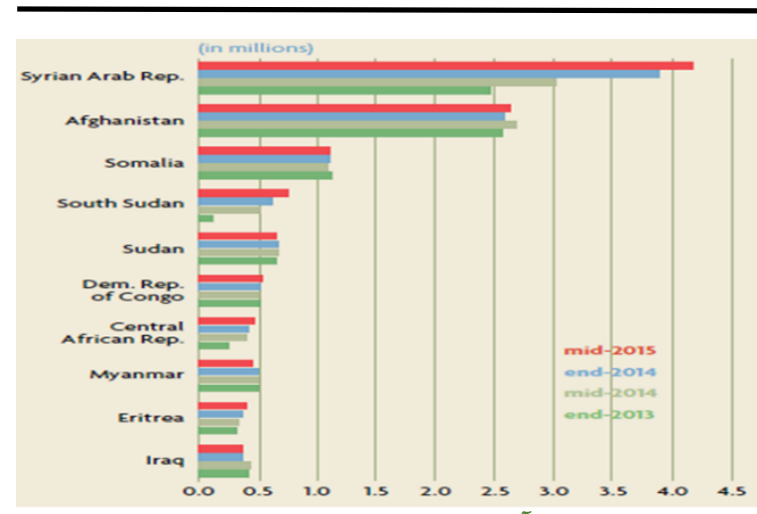

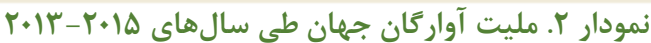

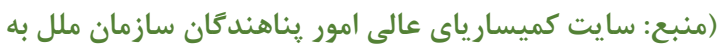

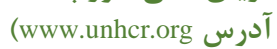

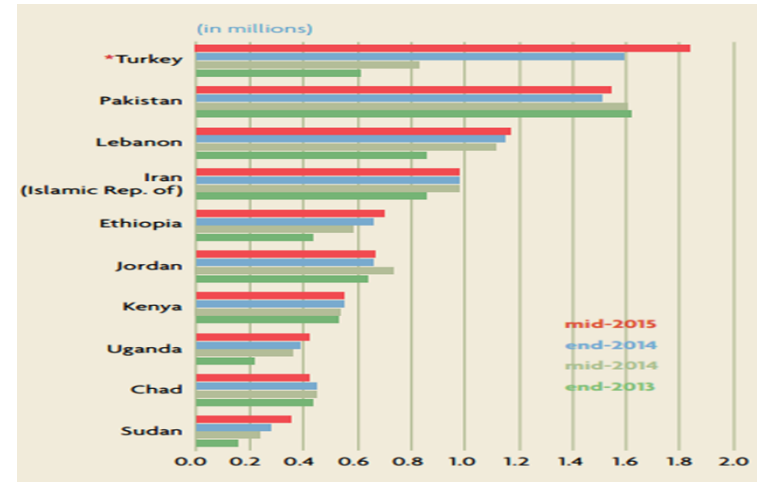

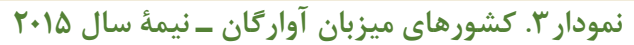

(منبع: سايت كميسارياى عالى امور يُناهندًان سازمان ملل به آدرس www.unhcr.org

اين واقعيت وجود دارد كه جابهجايى اجبارى و تطابق با يك كشور و زبان جديد همراه با ساير عوامل استرسزاي جائ آنائ ناشى از مشكلات اجتماعى و اقتصادى و فرهنكى كه آواركان

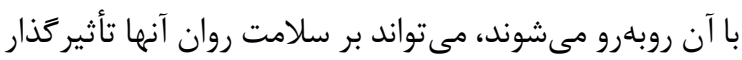
باشد (f(). أر جه تحقيقات مختلف به اهميت عوامل خطر مرتبط با سلامت روانى يس از بلايا از جمله ويزگى هاى

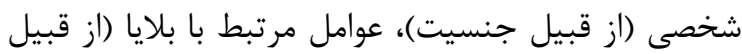
جراحت و آوارگى) و عوامل محيطى (مثل حمايت اجتماعى) يرداختهاند، با اين وجود اجماع و اتفاقنظر بر ماهيت، درجي إنه

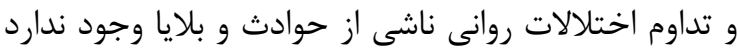

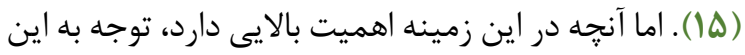
موضوع است كه سلامت روان جيزى فراتر از نبود اختلالات روانى است و ابعاد تأمين رشد و بهداشت روانى فردى و

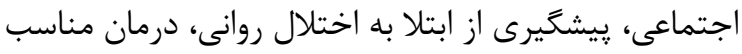

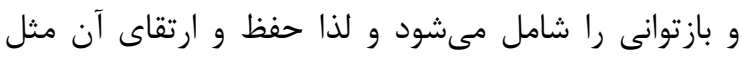

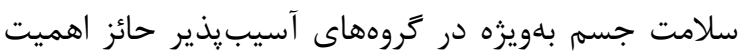

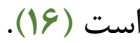

\section{الف) آواركى و اختلالات روانى}

محققين در زمينهُ بلايا به اين نتيجه رسيدهاند كه وقوع بلايا اعم از طبيعى يا انسانساخت وضعيت استرسزايى داني

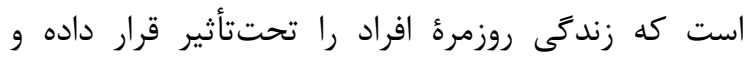

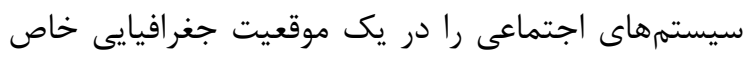

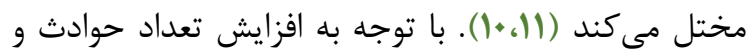

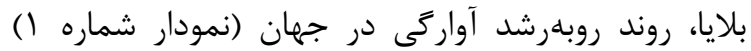
بهعنوان يكى از معضلات جامعهُ جهانى در ساليان اخير

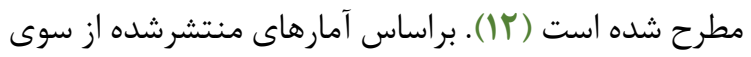

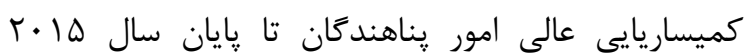

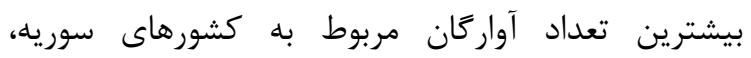

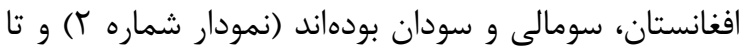

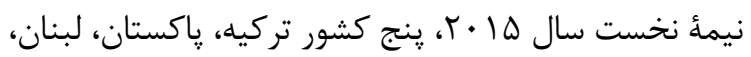
ايران و اتيويى ميزبان بالاترين تعداد آوارگان در جهان

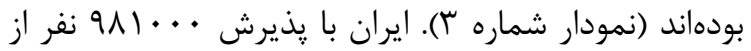

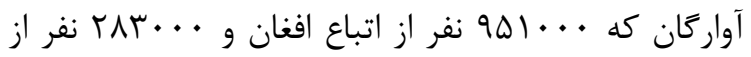
آواركان عراقى هستند، جزو ينج كشور اول جهان در يذيرش

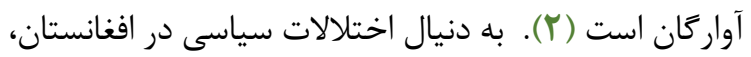
جمهورى اسلامى ايران و پاكستان طى سه دهو كذشته

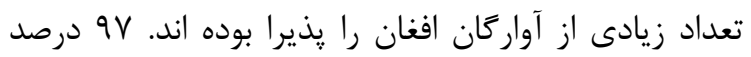

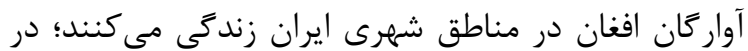

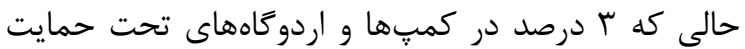

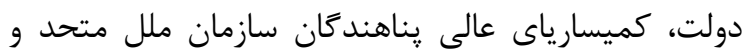
سازمانهاى غيردولتى خارجى ساكن هستند. در سال

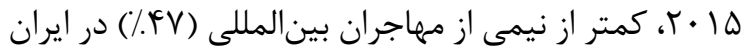

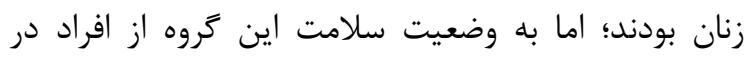

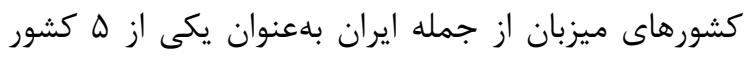
مطرح جهان در يذيرش آواركان، هركز بهطور جامع توجه آنهان آنهان

نشده است (ب) - (l).

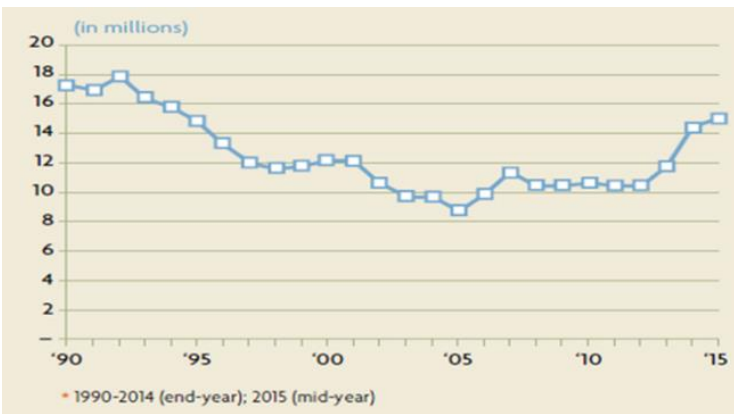

نمودار ا. روند تعداد آواركان تحت بوشش كميسارياى عالى بانى

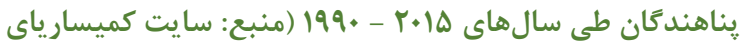

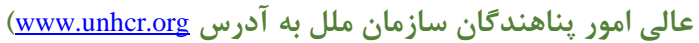


صحبت مىشود به نظر مىرسد كه زنان با خطر بيشترى

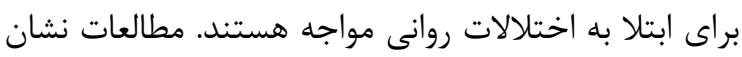

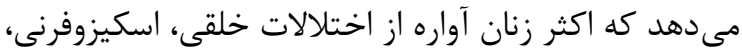

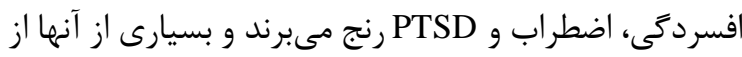
كمبود خواب، خستگى، احساس يارانوئيد، سيكوز و افكار

$$
\text { خودكشى شكايت دارند (Y). }
$$

ازهم گسيختكى روابط و شبكههاى اجتماعى متعاقب

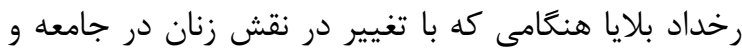

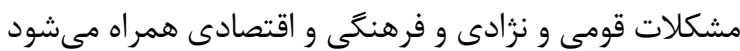
باعث تشديد اثرات زيانبار بلايا بر سلامت روان زنان منان مىشود

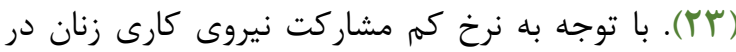

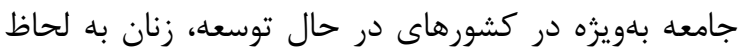

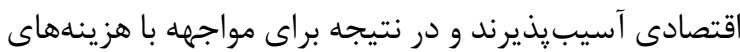

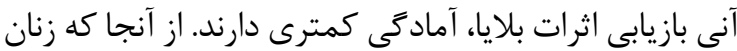
در جامعه در سطح اجتماعى קيايينتر نسبت به مردان قرار

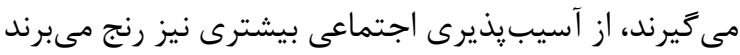
(YF)

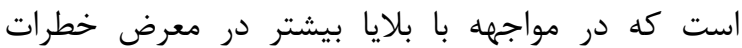

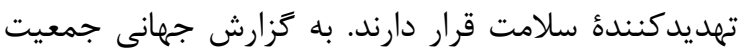

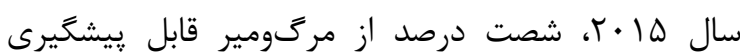
مادران بين زنانى رخ مىدهد كه سعى دارند از منازعات، حوادث طبيعى و نقل مكان اجبارى جان سالم بان بلهدر برند.

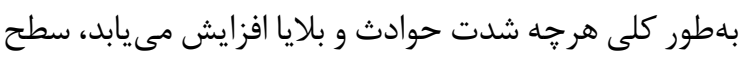
سلامت زنان كاهش يُيدا مى كند (rه). امروزه برآوردن نيازهاى سلامت زنان بهطور گسترده بلعنوان يك الزام انساندوستانه و رعايت و احترام به حقوق بشر يذيرفته شده

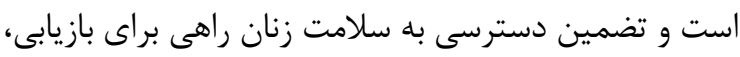

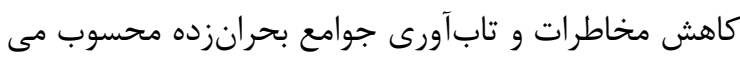

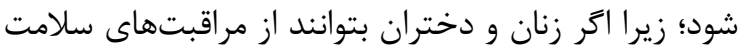

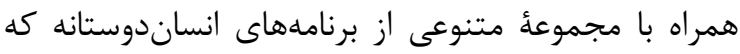

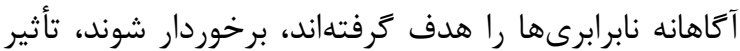
مثبت آن در تمام وجوه اقدامات انساندوستانه جارى خواهد إندان

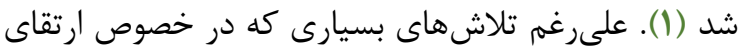

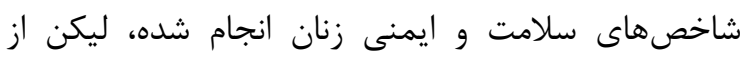

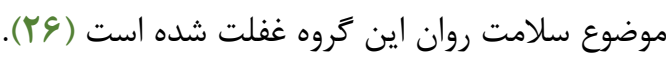
با توجه به اينكه نيازهاى زنان آواره متعدد و يِيجيده و روان

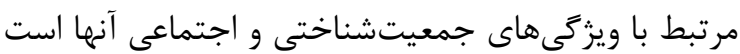

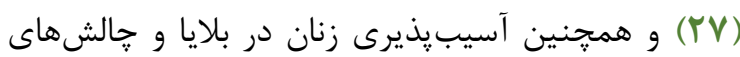

مطالعات انجامشده درباره سلامت روان آواركان متأثر از حوادث انسانساخت بلويزه جنگَها، حاكى از آن بوده

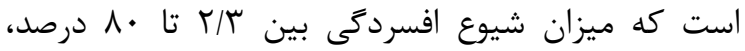

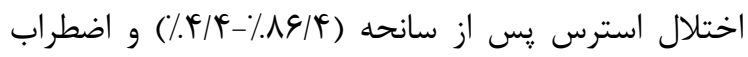

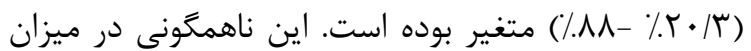

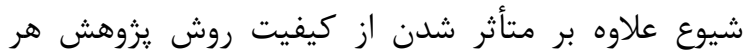
مطالعه، به كشورى كه آواركان از آن آمدهاند و كشورى كه كه

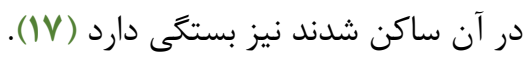

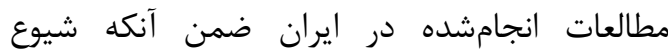
اختلالات روانى ميان آواركان بهويزه گروهى كه در كمبهات إنها

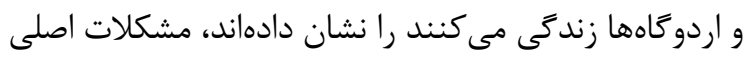

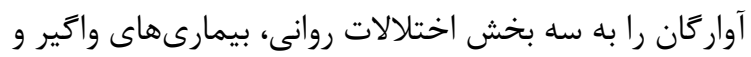

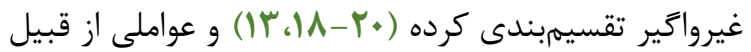
سن و جنسيت، ميزان سازكًارى فرهنكى و اجتماعى با جامعهُ

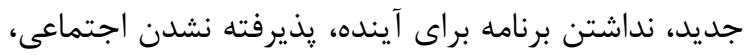

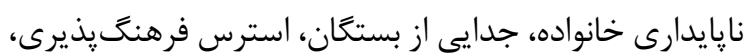
نبود حمايت اجتماعى، نداشتن نقش اجتماعى سودمند و

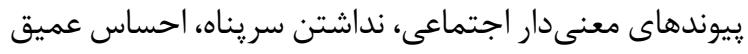

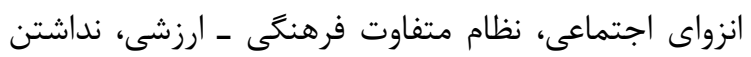
مهارتهاى اجتماعى، بيكارى يا اشتغال به كارهاى سخت،

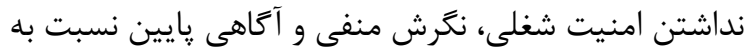

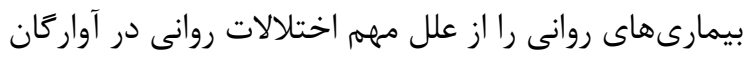
ايران برشمردند (19). باتوجه به اينكه زنان، سالمندان، متأهلها و افراد

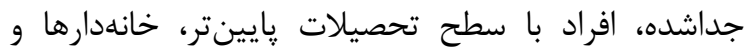
بيكارها از اختلالات روانى بيشترى در رنج هستند (19)، لذا

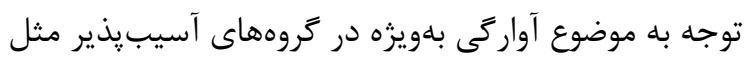

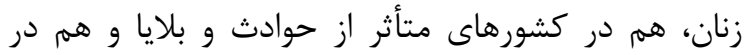
كشورهاى ميزبان از اهميت بسزايى برخوردار است.

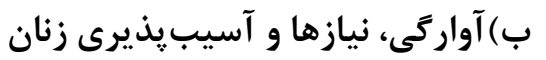

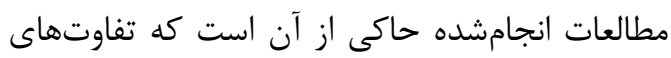
جشمخيرى بين زن و مرد در درك مشكلات و اختلالات

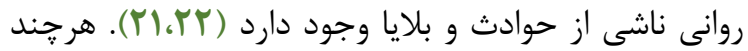

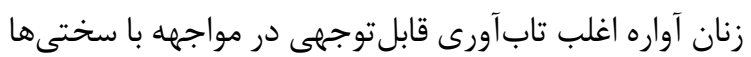

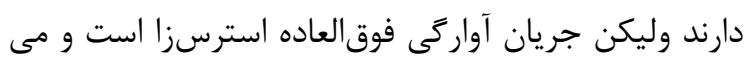
تواند بيامدهاى مهمى بر سلامت جسمى و روانى آنان داشته

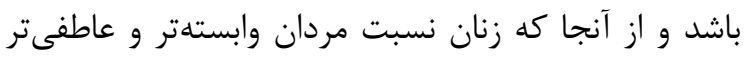

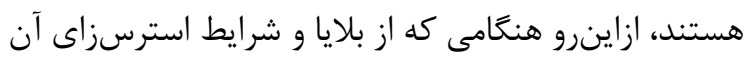


زنانى كه زنده مىمانند، موضوع نكران كنندهاى است. نبود و يا ضعف خدمات سلامت باكيفيت، يك واقعيت شايع براى اكثر زنان آواره است كه مىتواند منجر به ميزان بالاى مرى باتى

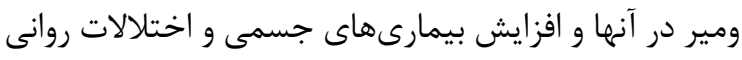

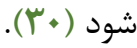

در زمان بلايا، زنان باردار بهدليل نيازمندى به مراقبت

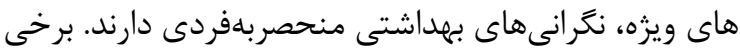

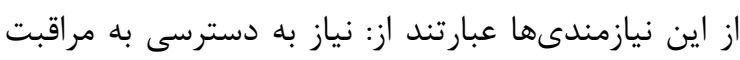

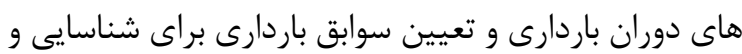

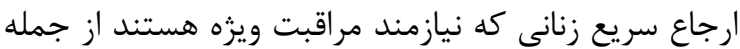

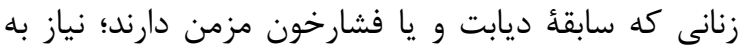
زايمان تميز؛ نياز به دسترسى به مراقبتهاى يس إنى از زايمان؛

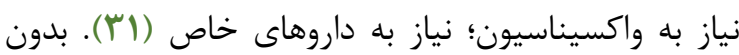
دسترسى به خدمات اورزانسى مامايى، زنان و نوزادان آنها

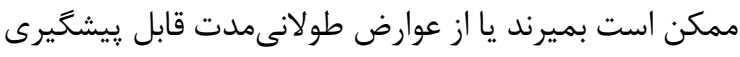

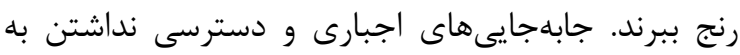
خدمات مناسب زنان و مامايى، بار روانى و جسمى سنكينى إنى را بلويزه بر زنان باردار تحميل مى كند (T (Y). يكى ديكر از نيازمندىهاى زنان در بلايا نياز به وسايل

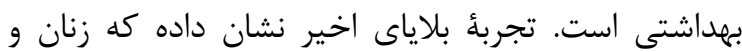

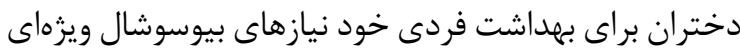
دارند. تغيير مكانهاى اجبارى بهطور معمول دسترسى به به بهائ

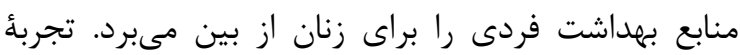

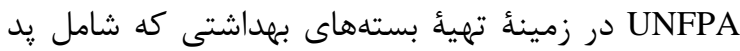
بهداشتى، صابون و حوله و همجنين مواد اضافهاى كه زنان

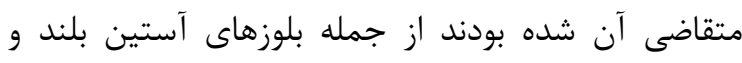

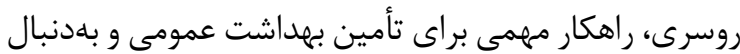

$$
\text { آن آرامش روانى سلامت زنان بود (YT). }
$$

آسيبذيذى بالاى زنان و كودكان در شرايط

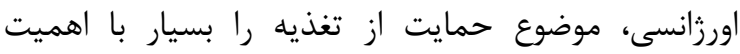
مى سازد. در ريناهكاهها زنان اغلب دسترسى كمترى به منابع دارند و ممكن است بهطور نامتناسبى از مشكلاتى مثل سوءتغذيه رنج ببرند. موادغذايى اغلب در بين مردان خانواده توزيع شده و اغلب مردان و يسران قبل از زنان و دختران غذان

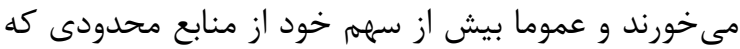

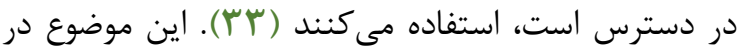
زنانى كه نوزاد شيرخوار دارند بحرانىتر است و علاوه بر دراس

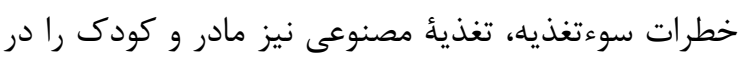

آنها در پِاسخ به مشكلات و بهبود شرايط پِ از بلايا، خطر بروز اختلالات و بيمارىهاى روانى رادر زنان افزايش مىدهد

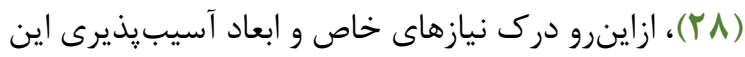
كروه از افراد و جالشها و موانع موجود در ياسخ به نيازهاى آنها در خدماترسانى اثربخش ضرورى است. خنين دركى شيوه خدماترسانى را بهبود بخشيده و تنظيم شرايط براى زندگى آنها را تسهيل مى كند (YV). در اين راستا نيازها و آسيبذيذيرى روانى ـ اجتماعى اين گروه از افراد در ابعاد

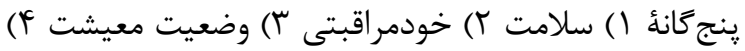
سرمايه اجتماعى و ه) حمايت اجتماعى طبقهبندى و بررسى

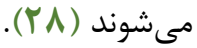

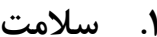

وضعيت تغذيه و سلامتى اولئ افراد (اعم از جسمى و روانى) كه در زندگى روزمره قبل از تأثير مخاطرات مطرح

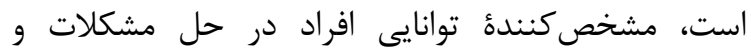
بيمارىها و انواع آسيبهاى ناشى از حوادث و بلايا است.

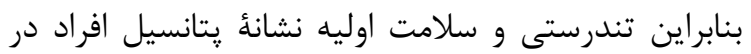

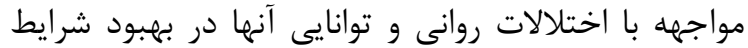

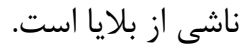

صندوق جمعيت سازمان ملل متحد UNFPA در سال

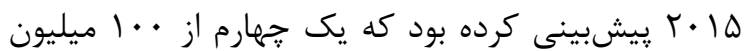
نفرى كه به كمكهاى بشردوستانه نيازمندند، زنان و دختران نوجوانى هستند كه در سنين بارورى قرار دارند. بنابراين

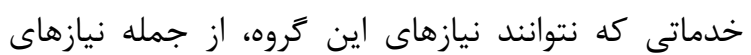

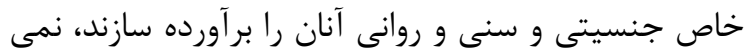
توان در رديف خدمات مؤثر به حساب آورد (1). در بحث سلامت اوليه لازم است تا به تفاوتهاى جنسيتى كه يكى از ابعاد اجتماعى تأثير كذار بر سلامت روان الان التان زنان است، توجه شود. اين حقيقت وجود دارد كه بـعدالتى آنى جنسيتى، نوع متفاوتى از آسيبيذيرى است است كه در سلامت

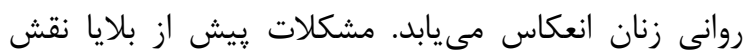

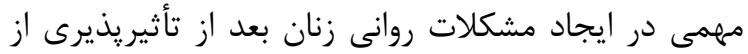
يكى بلاياى طبيعى يا انسانساخت دارند. فشارهاى روزانه

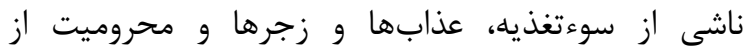
مراقبتهاى بهداشتى ـ درمانى، از عوامل ايجادكننده

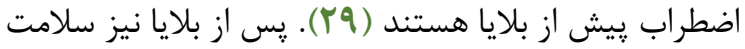


بازماندًان، جلوَيرى از انتقال HIV، جلو ميرى از افزايش

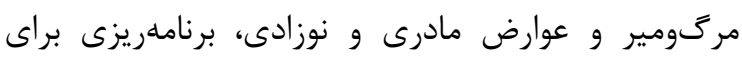

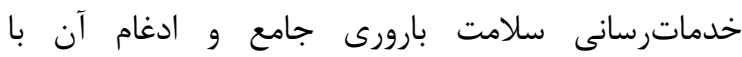

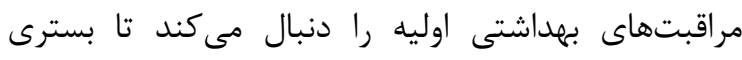

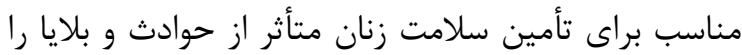

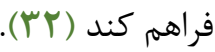

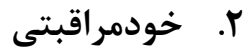

خودمراقبتى، مهارت فرد يا اعضاى خانواده در

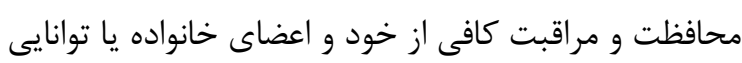

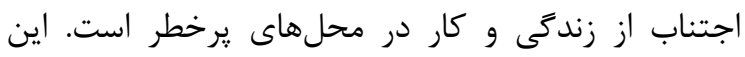

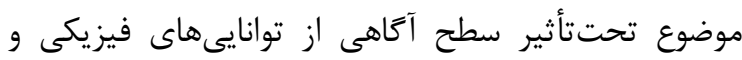

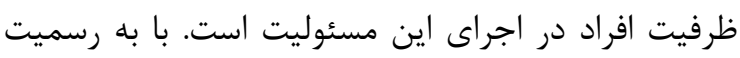

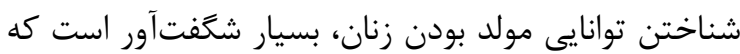

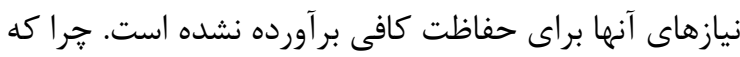

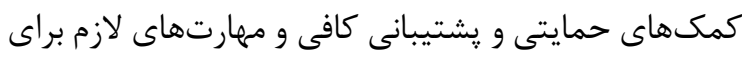

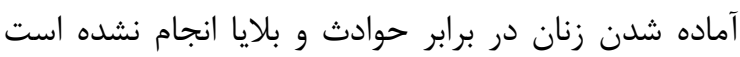

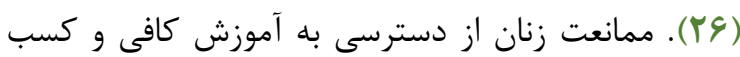
مهارتهاى لازم و كاهش تعاملات اجتماعى آنها مىتواند

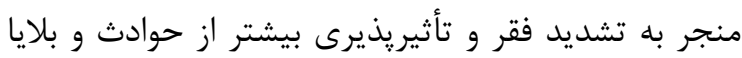

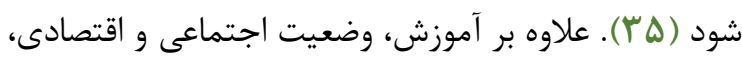

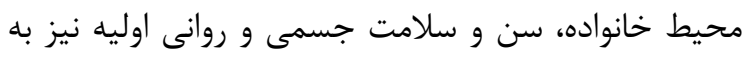

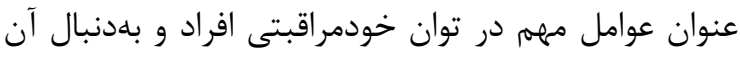

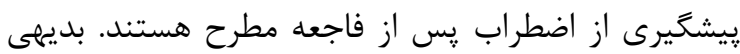

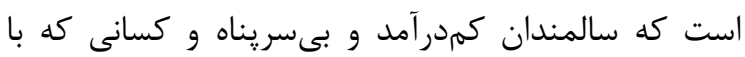
معلوليت جسمى و شناختى مواجه هستند، با موانع و و مشكلات بيشترى در زمينهُ تخليه، جابهجايى و اسكان مجدد

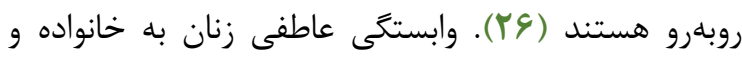

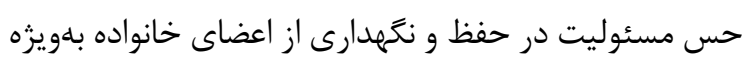
فرزندان و همجنين مسائل فرهنكى و مذهبى و اعتقادات و

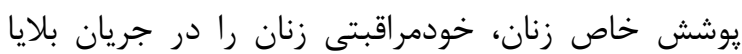

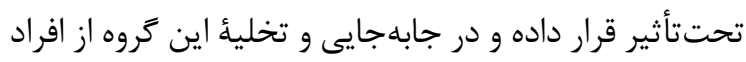

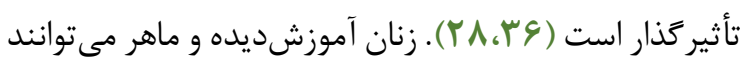

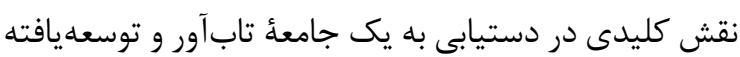

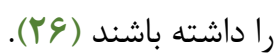

\section{r. . وضعيت معيشت}

وضعيت معيشتى بلمعنى ظرفيت و توان فرد در حل

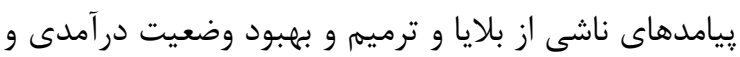

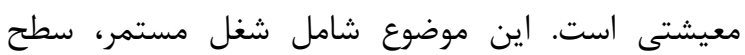

معرض خطر قرار مى دهد. لذا توجه به تأمين غذا و مغذىها

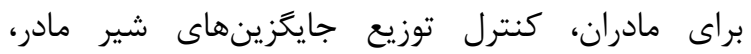

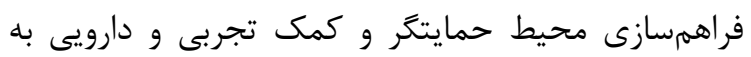

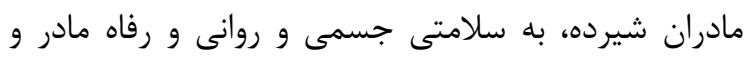

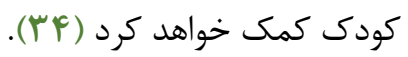
در بلايا، توزيع زودهنكام روشهاى ضداردارى

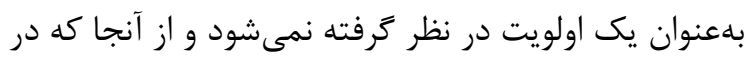
اين شرايط مردم بلهنبال حمايت احساسى هستند، اغلب دران

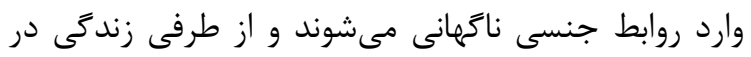

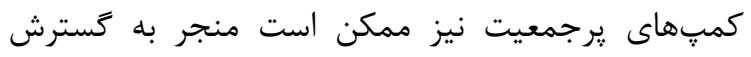

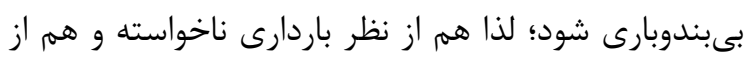

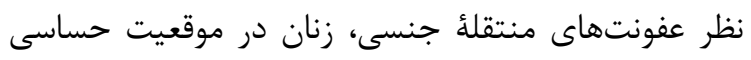

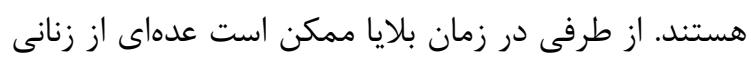

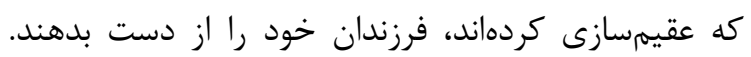

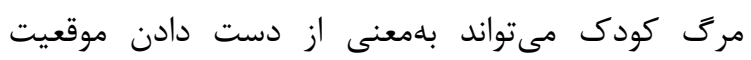

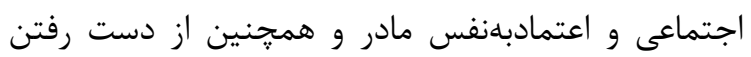

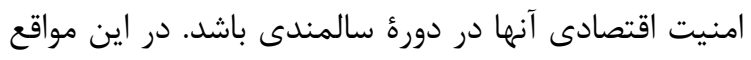

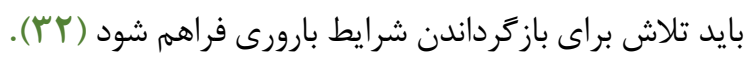

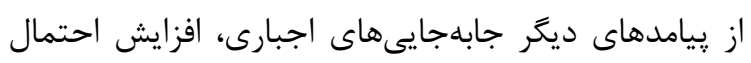

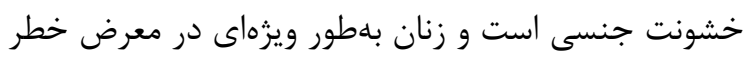

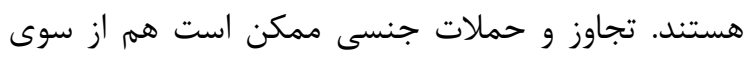

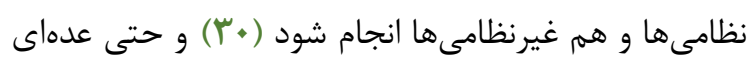

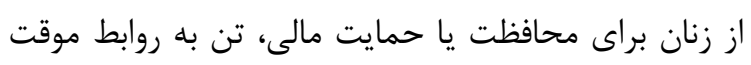

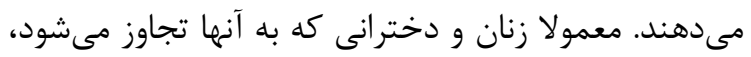

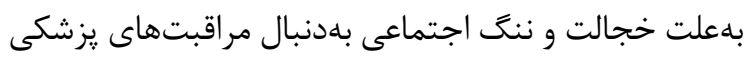

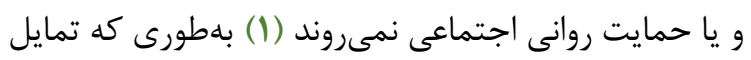

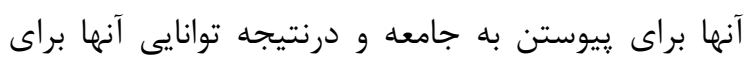

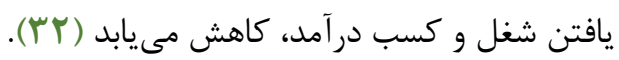

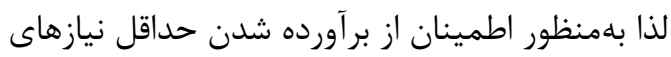

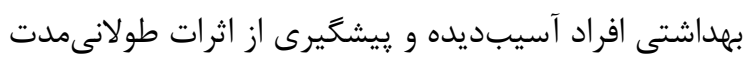

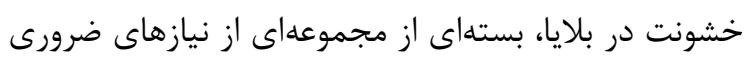

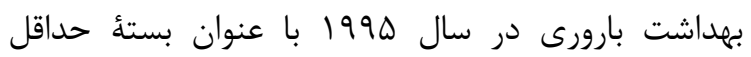
خدمات اوليه (MISP) تدوين شد. هدف MISP كاه بال

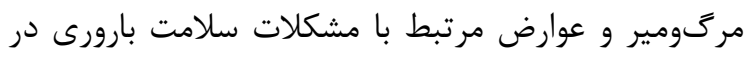

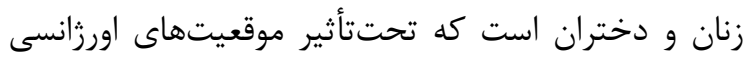

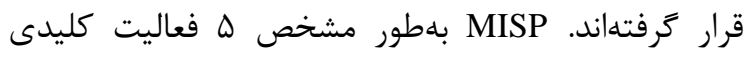

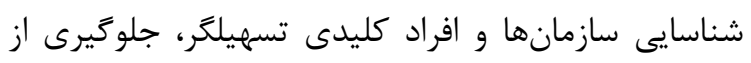

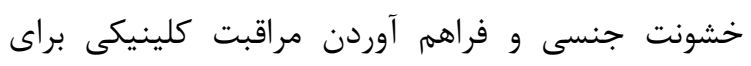




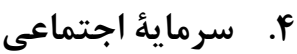

سرمايه اجتماعى يك واحد ساختارى از شبكهها،

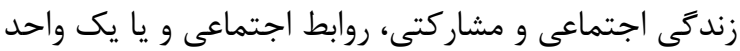
ادراكى از حمايت دريافتى، ييوستگى اجتى اجتماعى و ائتلاف

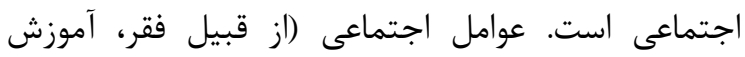
ناكافى، زندگى در محيطهاى يرخطر، خشونت و تصادفات)،

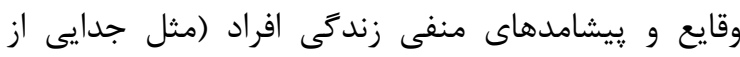

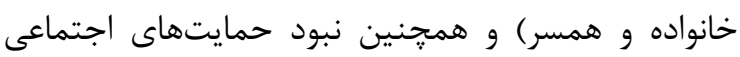
بلهعنوان ابعاد مختلف سرمايئ اجتماعى، به شيوههاى متفاوت بر سلامت روانى افراد تأثير كذار است. نتايج تحقيقات حاكى إنى از آن است كه سرمايههاى اجتماعى مى توانند كاهش دهندئ

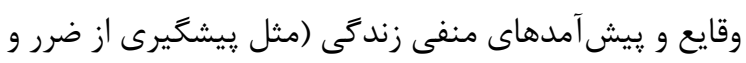
زيانهاى شغلى) و مشكلات بلندمدت (از قبيل وضعيت

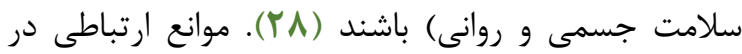

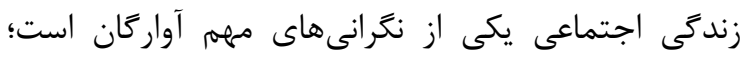

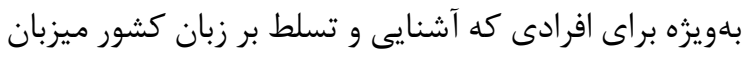

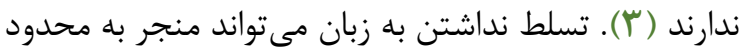
كردن توانايى زنان در تعاملات اجتماعى و بهدست آوردن

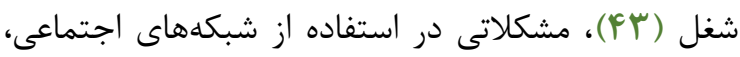

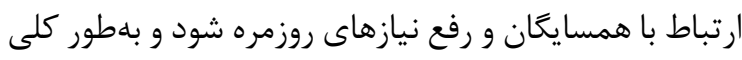

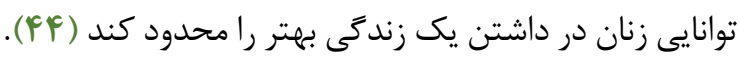

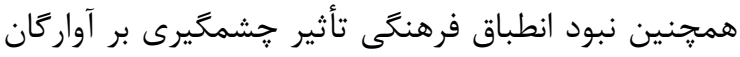

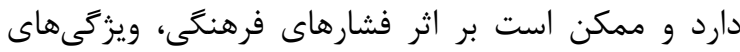

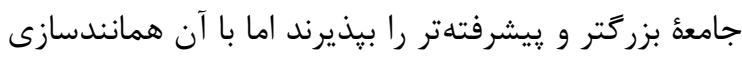

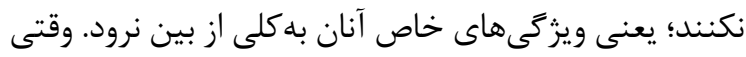

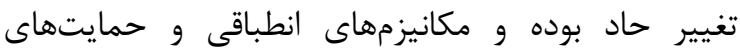

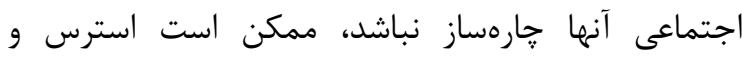

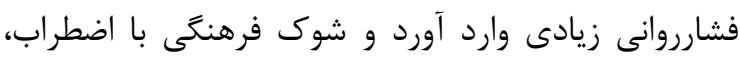
افسردگى، مسخ واقعيت و مسـخ شخصيت ويزه را بههمراه داشته باشد (19). لذا خطر ابتلا به انزواى اجتماعى در زنان

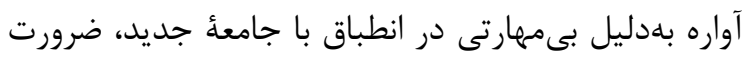

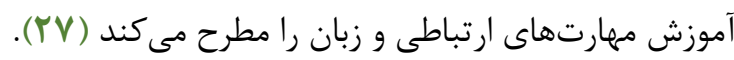

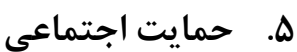

حمايت اجتماعى به ظرفيت و يا تمايل ساختارهاى

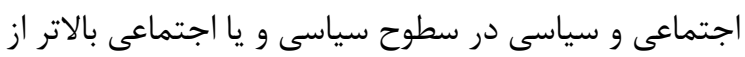
فرد يا خانوار، براى محفاظت (بهويزه ساختارى و آمادهسازى دياتي فنى) در برابر مخاطرات اشاره دارد. حمايت اجتماعى به به بهارئ
يسانداز، مزاياى رفاهى، توان حمايتى اعضاى خانواده است

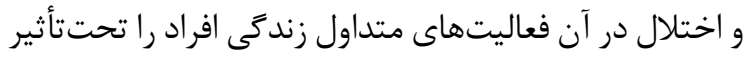

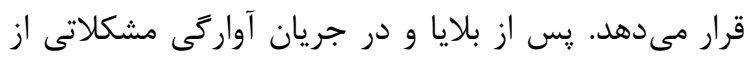

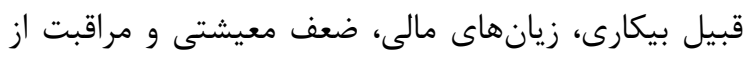
خانواده در تطابق با كشور جديد بر بسيارى از زنان آواره بار اضافى تحميل مى كند. ظرفيت زنان در اينكه بتوانند از عهده إندان

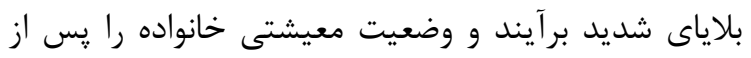

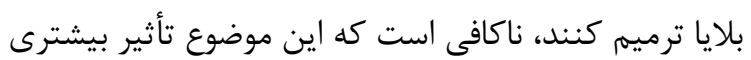

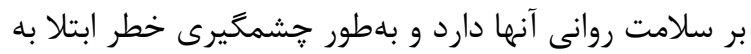
بيمارىها و اختلالات روانى را از قبيل افسردكى، اضطراب، إنهاب استرس و حتى شكايتهاى بالينى و دردهاى جسمى، در إنى

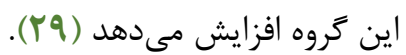
اغلب زنان آواره يا بيكارند يا در صنايع كمدرآمد مشغول به كار هستند (YV). تعارض نقشها و فشار

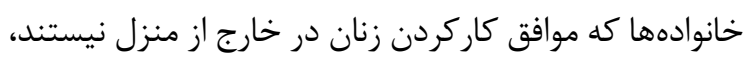

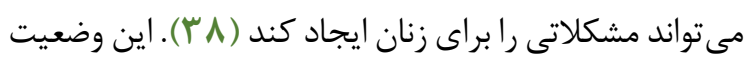

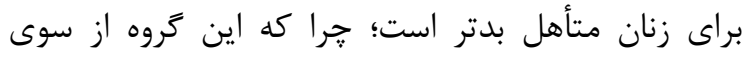

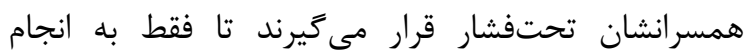
مسئوليتهاى خانهدارى بيردازند. در نتيجه زنان فيرنان متأهل

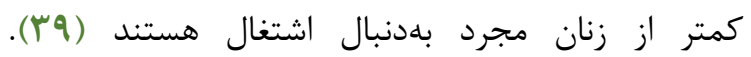
نكرانى هاى مالى براى زنان سريرست خانوار كه ممكن است

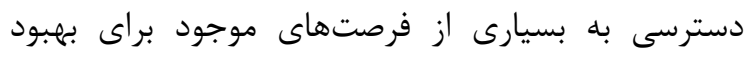

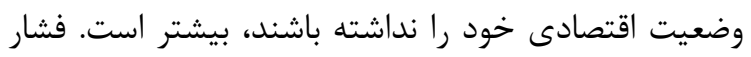

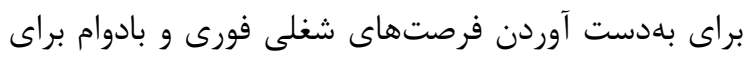

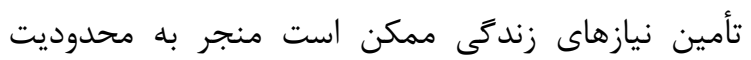

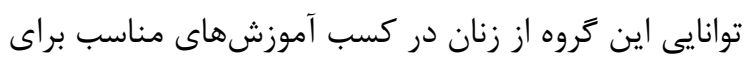

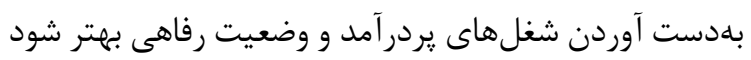

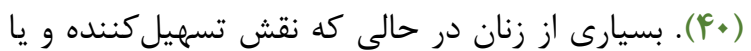

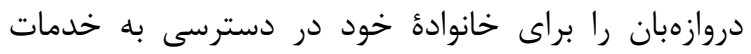

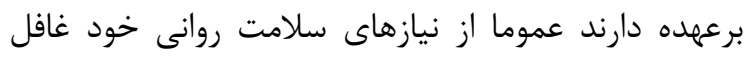

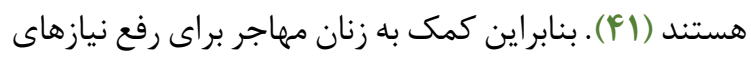

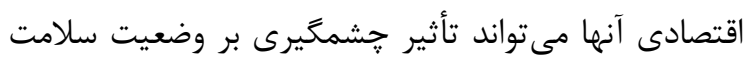

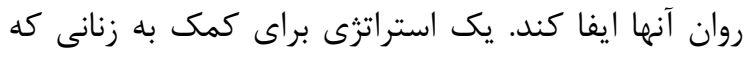

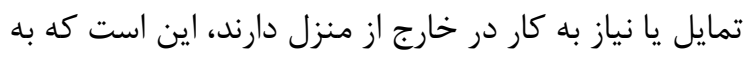

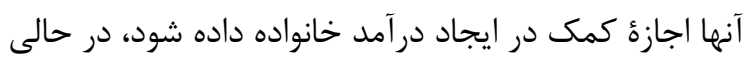
كه مسئوليت خانوادكى خود را نيز حفظ مى كنند (FY). 
موانع متفاوتى در دريافت خدمات بلويزه خدمات سلامت

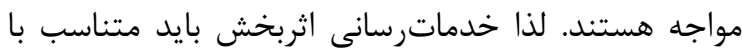

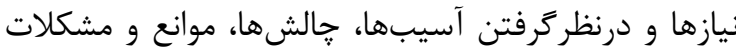

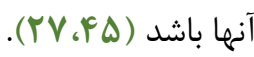

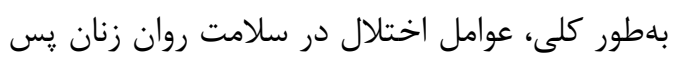
از بلايا در سه حيطه قابل بررسى است: الف) شدت حوادث

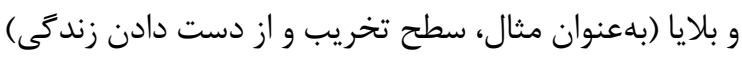

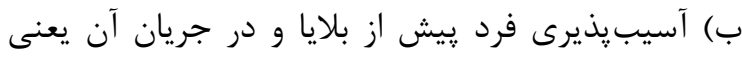

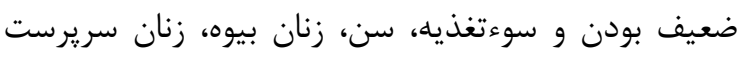

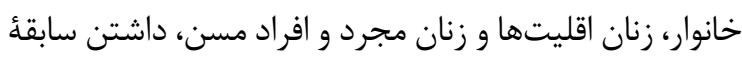

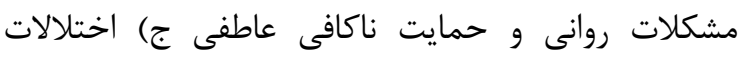

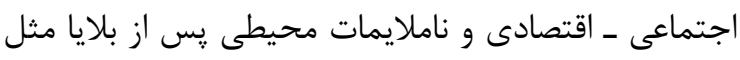

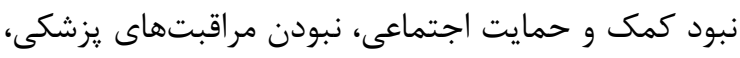

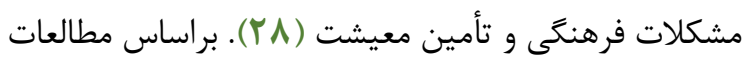

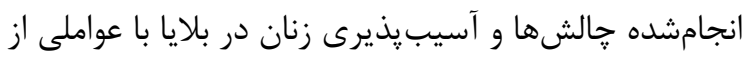

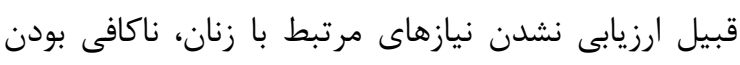

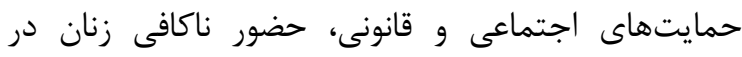

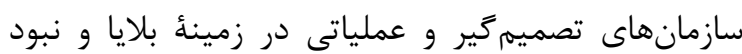

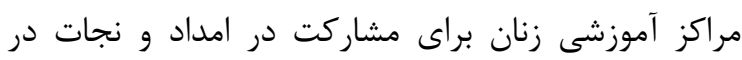

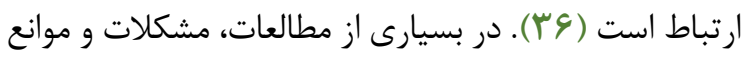

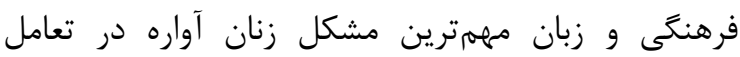

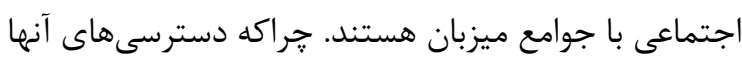
را به منابع و خدمات موجود بهويزه خدمات جنات سلامت محدود

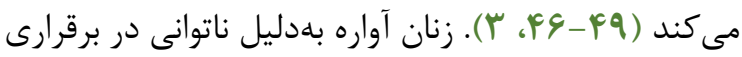

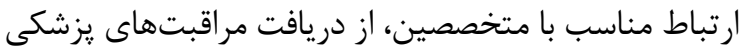

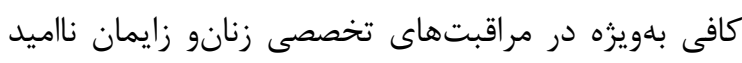

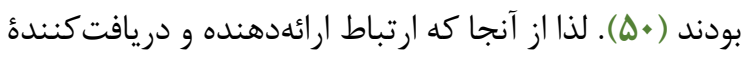

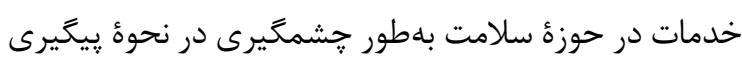

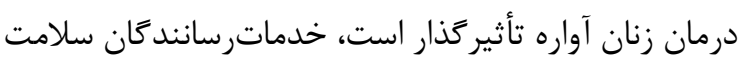

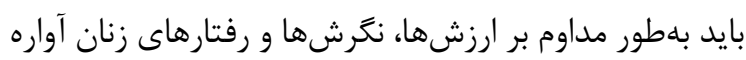

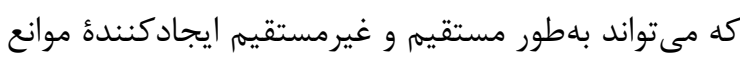

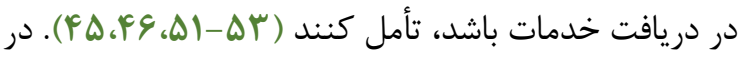
برخى كشورها براى اطمينان از راحتى و دسترسى آوات داركان

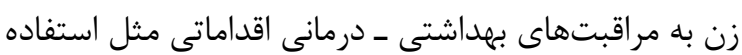

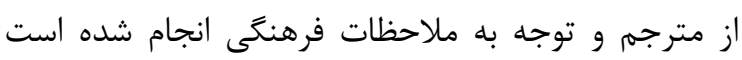

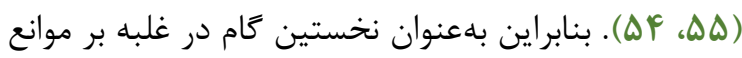

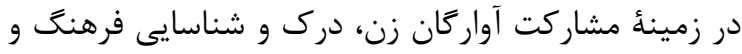

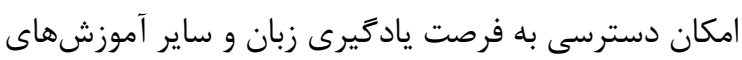

موضوع ايمنى افراد بهويزه افراد فقير و كروههاى آسيبيذير

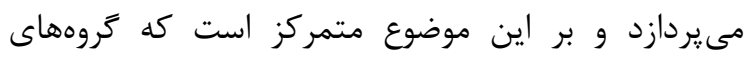

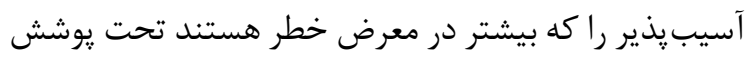
قرار دهد و فرصتهايى براى آنها مهيا كند تا بتوانند خطرات را رشت سر حذارند. تحقيقات حاكى از آن است كه اغلب زنان از فرايندهاى

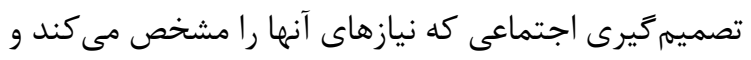

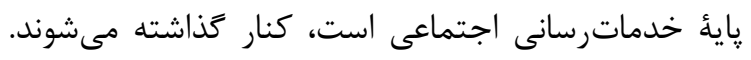

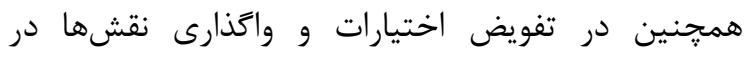

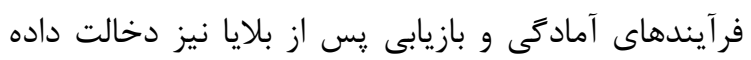

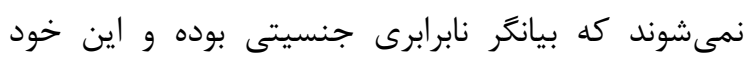

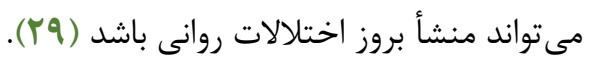

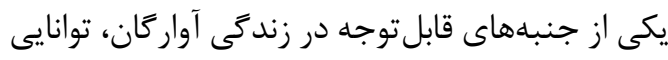

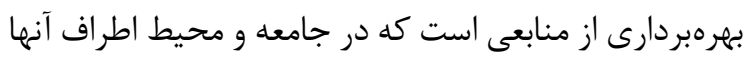

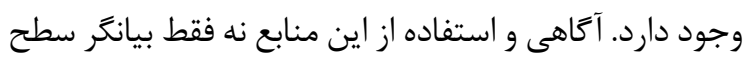
راحتى و تطابق افراد با محيط جديد است، بلكه توانايى آنها

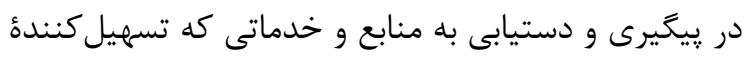

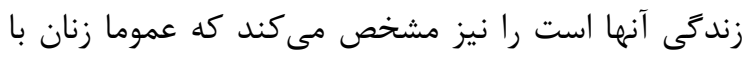

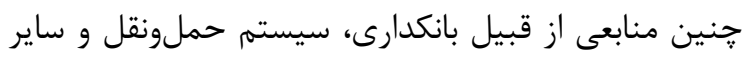

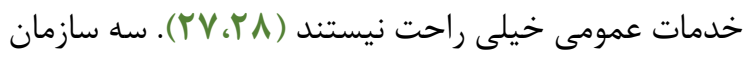

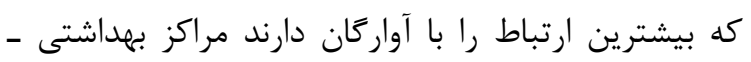

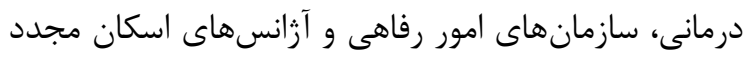

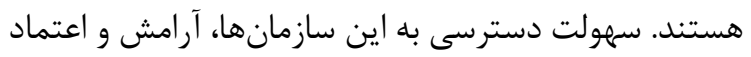

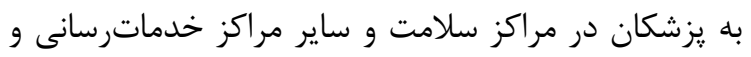

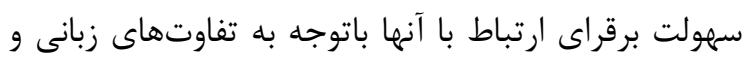

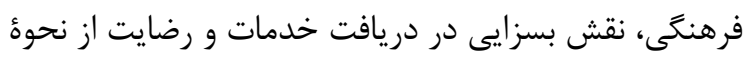

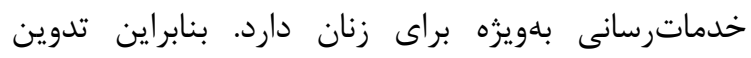

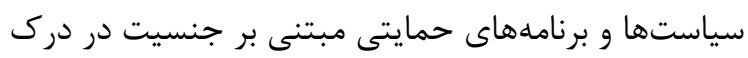

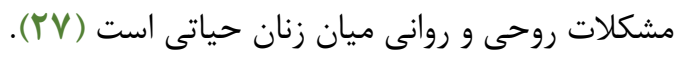

\section{بحث}

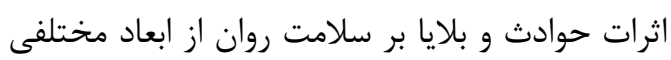

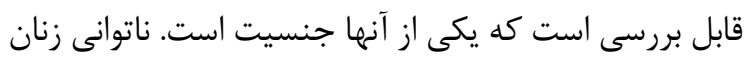
براى تحقق نيازهاى خود در جريان بلايا و يا حتى مشكلات است آنات

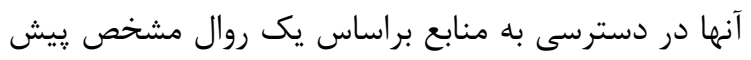

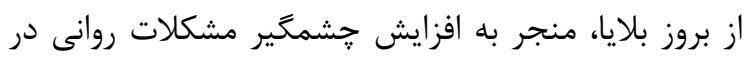

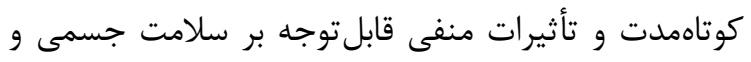

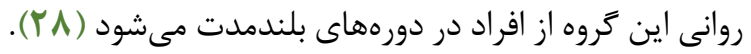

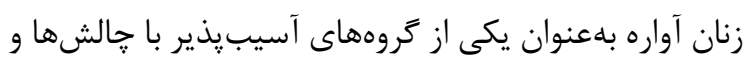


دريافت خدمات مناسب سلامت روان است (\&\&). اين

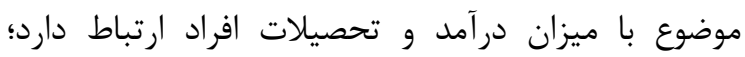

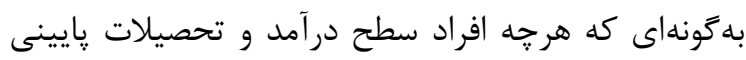

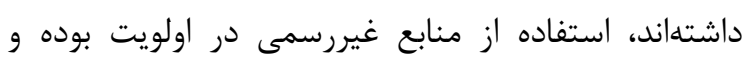

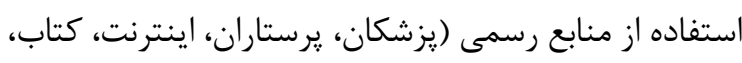

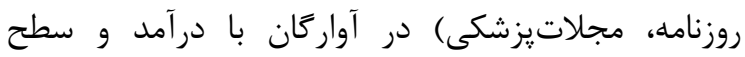

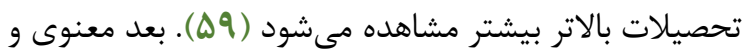

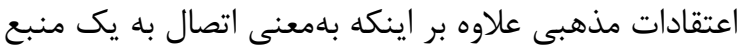

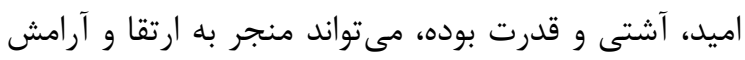

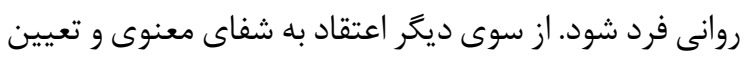

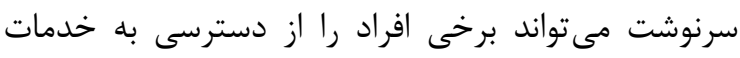

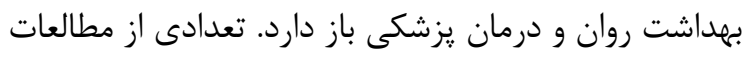

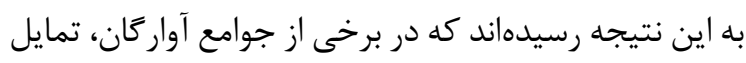

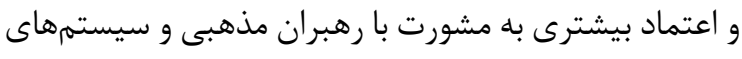

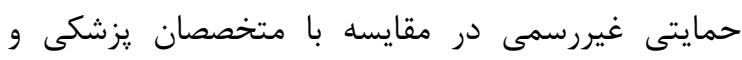

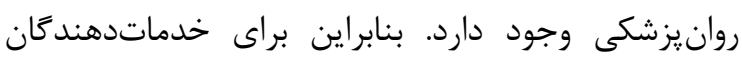
مراقبت هاى سلامت به رسميت شناختن قدرت نورد نفوذ مذهب

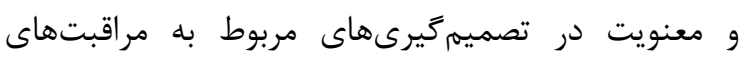

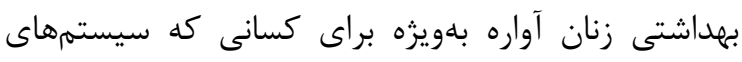

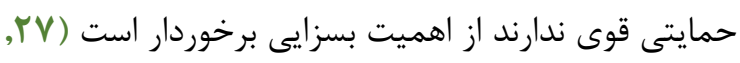

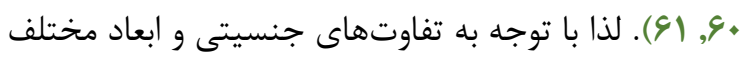

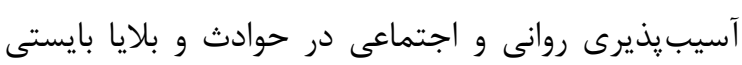

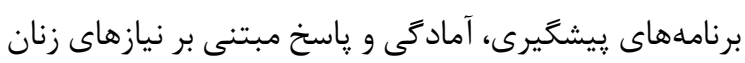

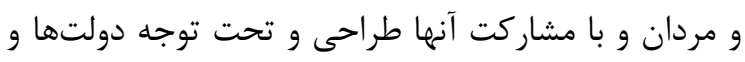

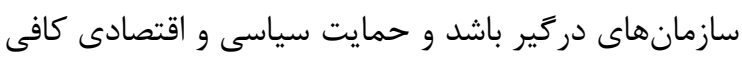

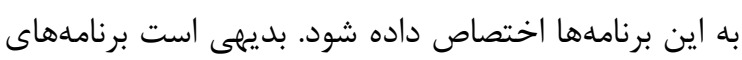

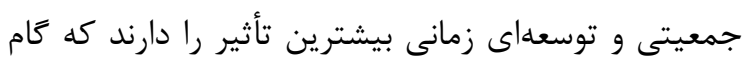

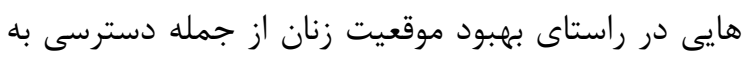

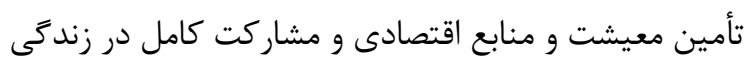
اجتماعى برداشته شود.

\section{سباسگزَارى}

بدين وسيله نويسندًان بر خود لازم مى دادند مراتب

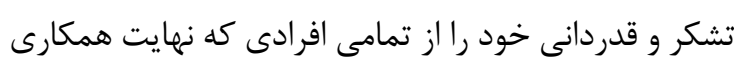
را در اجراى اين مطالعه داشتند بهعمل آورند.

$$
\text { تعارض در منافع }
$$

بين نويسندكان هيجَّنه تعارض در منافع كزارش
مهارتى مى تواند تأثير جشمخيرى در بهبود وضعيت زندكى إنى

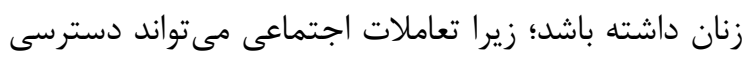

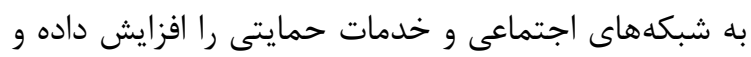

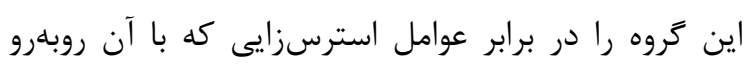

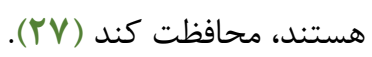
تحقيقات نشان دادهاند كه نيازهاى مالى و اقتصادى مهادي

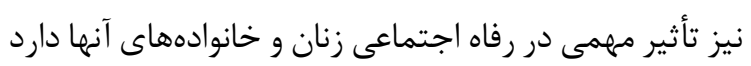

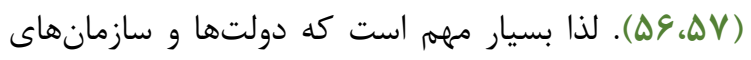
بشردوستانهُ ملى و بينالمللى بر رفع نيازهاى اقتصادى زنان

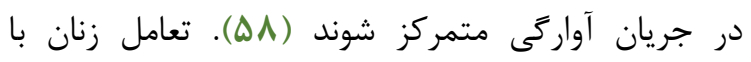

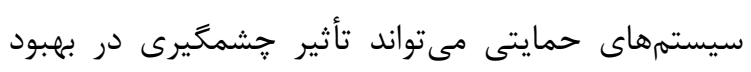

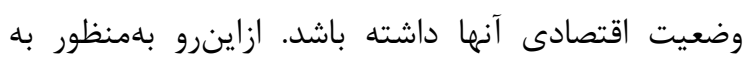

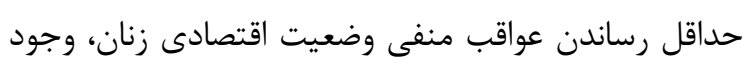

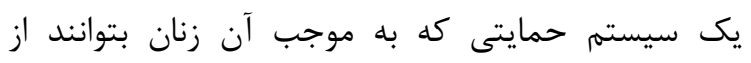

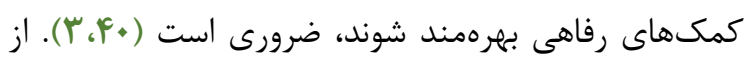

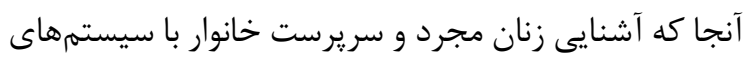

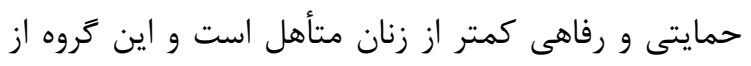

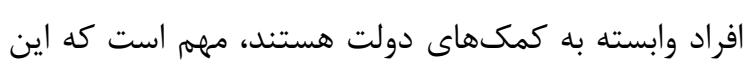

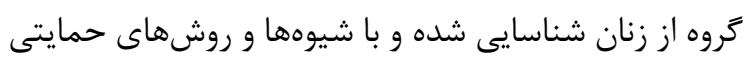
و نحوهُ بهرهبردارى از اين كمكها آشنا شوند (11).

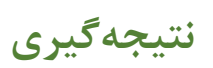

مطالعات انجامشده در خصوص آسيبذيذيرى روانى

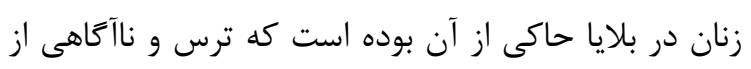

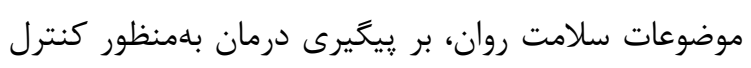

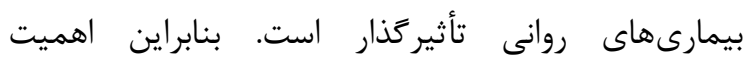

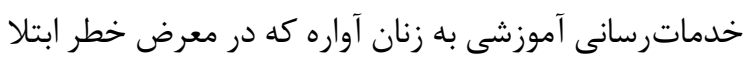

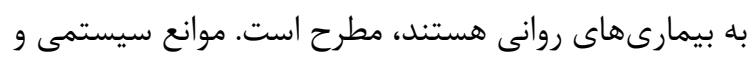

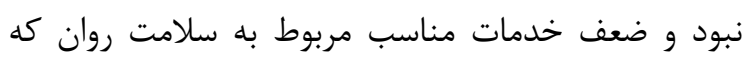

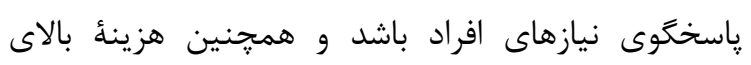

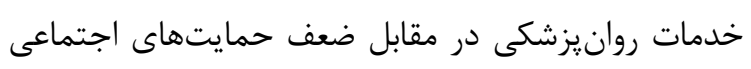

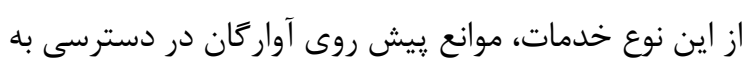

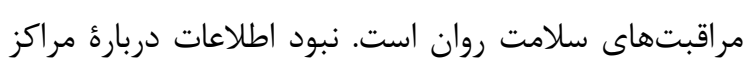
خدماتدهندة رواندرمانى، موضوع اطلاعرسانى و تبليغات

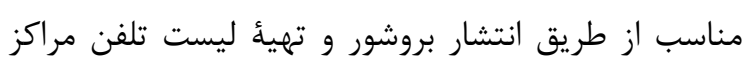

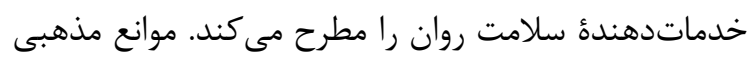

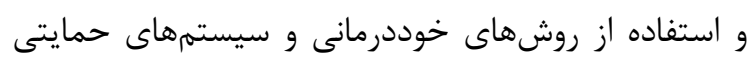

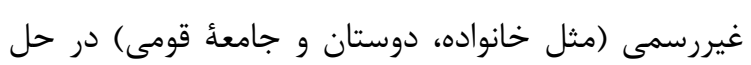

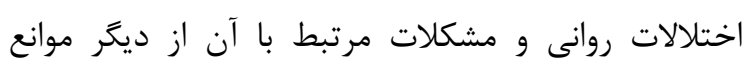




\section{References}

1. McGinn $\mathrm{T}$, Bhabha J, Garfield R, Johnson $\mathrm{K}$, Luchsinger G, Oddy L, et al. State of world population 2015. Shelter from the storm. A transformative agenda for women and girls in a crisis-prone world. 2015.

2. UNHCR. report confirms worldwide rise in forced displacement in first half 2015. Geneva, Switzerland: The UN Refugee Agency, 2015.

3. Bulman KH, McCourt C. Somali refugee women's experiences of maternity care in west London: a case study. Crit Public Health. 2002;12(4):365-80. https://doi.org/10.1080/0958159021000029568

4. Aboobacker NP, Nakray K. Gender mainstreaming in disaster management policies: Indicators to mitigate vulnerability of women. University of Yourk. 2011. PMid:22194185

5. Martin SF. Refugee women(Program in Migration and Refugee Studies).2nd ed. Lanham, MD: Lexington books; 2004.

6. Crawford E, Swenson F, Serrani A, Cassidy K, Roy B, Porter T. Grant Application: Immigrant And Refugee Family Wellness Engagement Through Yoga And Zumba. 2014.

7. Bhugra D, Jones P. Migration and mental illness. Adv Psychiatr Treat. 2001;7(3):216-22. https://doi.org/10.1192/apt.7.3.216

8. Organization WH. Mother-baby package: implementing safe motherhood in countries: practical guide. Geneva: World Health Organization; 1996.

9. Aitsi-Selmi A, Egawa S, Sasaki H, Wannous C, Murray V. The Sendai framework for disaster risk reduction: renewing the global commitment to people's resilience, health, and well-being. IJDRS. 2015;6(2):164-76. https://doi.org/10.1007/s13753015-0050-9

10. Barton AH. Communities in disaster: A sociological analysis of collective stress situations: Garden City, NY: Doubleday; 1969.

11. Taylor AJW. Disasters and disaster stress. New York: Ams Press; 1989.

12. Prince M, Patel V, Saxena S, Maj M, Maselko J, Phillips MR, et al. No health without mental health. The lancet. 2007;370(9590):859-77. https://doi.org/10.1016/S0140-6736(07)61238-0

13. Divkolaye NSH, Burkle Jr FM. The Enduring Health Challenges of Afghan Immigrants and Refugees in Iran: A Systematic Review. PLoS currents. 2011;9.

14. Pumariega AJ, Rothe E, Pumariega JB. Mental health of immigrants and refugees. Community Ment
15. Health J. 2005;41(5):581-97. https://doi.org/10.1007/s10597-005-6363-1 PMid:16142540

16. Perry RW, Lindell MK. The psychological consequences of natural disaster: A review of research on American communities. Mass Emergencies. 1978;3(2-3):105-15.

17. Caplan G. An approach to community mental health. London: Tavistock Publications; 1961. PMCid:PMC1939472

18. Bogic M, Njoku A, Priebe S. Long-term mental health of war-refugees: a systematic literature review. BMC Int Health Hum Rights. 2015;15(1):29. https://doi.org/10.1186/s12914-015-0064-9 PMid:26510473 PMCid:PMC4624599

19. Azizi F, Holakoie Naieni K, Rahimi A, Amiri M, Khosravizadegan F. Prevalence of mental health disorders and its associated demographic factors in resettled Afghan refugees of Dalakee Refugee Camp in Bushehr Province 2005. ISMJ. 2006;9(1):85-92.

20. Mohammadian M, Dadfar M, Bolhari J, Karimi Keisami E. Screening for mental disorders among Afghan immigrants residing in Tehran. Iran $\mathbf{J}$ Psychiatry Clin Psychol. 2005;11(3):270-7.

21. Noorbala A, Yazdi SB, Yasamy M, Mohammad K. Mental health survey of the adult population in Iran. $\mathrm{Br} \quad \mathrm{J} \quad$ Psychiatry. 2004;184(1):70-3. https://doi.org/10.1192/bjp.184.1.70 PMid:14702230

22. Hearne B, Peacock WG, Gladwin H. A gendered perspective. Hurricane Andrew: Ethnicity, gender and the sociology of disasters. London: Routledge; 1997.52-74.

23. Fisher S. Violence against women and natural disasters: Findings from post-tsunami Sri Lanka. Violence against women. 2010;16(8):902-18. https://doi.org/10.1177/1077801210377649 PMid:20679186

24. Abolghasemi H, Navidi A, Mohebi H. Health aspects of crisis management in unexpected accidents. Journal Mil Med. 2002;4(2):93-8.

25. Nolen-Hoeksema S. Gender differences in depression. Curr Dir Psychol Sci. 2001;10(5):173-6. https://doi.org/10.1111/1467-8721.00142

26. Swatzyna RJ, Pillai VK. The effects of disaster on women's reproductive health in developing countries. Glob J Health Sci. 2013;5(4):106-13. https://doi.org/10.5539/gihs.v5n4p106 PMid:23777727 PMCid:PMC4776806

27. Bell SA, Lori J, Redman R, Seng J. Development of a brief screening tool for women's mental health assessment in refugee settings: A psychometric evaluation. Int J Nurs Stud. 2015;52(7):1202-8. https://doi.org/10.1016/j.ijnurstu.2015.04.003 PMid:25892280 PMCid:PMC4912842

28. Deacon Z, Sullivan C. Responding to the complex and gendered needs of refugee women. Affilia. 2009;24(3):272-84. https://doi.org/10.1177/0886109909337401

29. Parida PK. Natural Disaster and Women's Mental Health. Social Change. 2015;45(2):256-75. https://doi.org/10.1177/0049085715574189 
30. Cannon T. Vulnerability analysis and disasters. Floods. 2000;1:45-55.

31. Chynoweth SK. The need for priority reproductive health services for displaced Iraqi women and girls. Reprod Health Matters. 2008;16(31):93-102. https://doi.org/10.1016/S0968-8080(08)31348-2

32. Callaghan WM, Rasmussen SA, Jamieson DJ, Ventura SJ, Farr SL, Sutton PD, et al. Health concerns of women and infants in times of natural disasters: lessons learned from Hurricane Katrina. Matern Child Health J. 2007;11(4):307-11. https://doi.org/10.1007/s10995-007-0177-4 PMid:17253147

33. Shishehgar S, Dolatian M, Majd HA, Bakhtiary M. Perceived pregnancy stress and quality of life amongst Iranian women. Glob J Health Sci. 2014;6(4):270-77.

https://doi.org/10.5539/gjhs.v6n4p270

PMid:24999152 PMCid:PMC4825377

34. Hynes M, Cardozo BL. Observations from the CDC: Sexual violence against refugee women. J Womens Health Gend Based Med. 2000;9(8):819-23. https://doi.org/10.1089/152460900750020847 PMid:11074947

35. Gribble KD, McGrath M, MacLaine A, Lhotska L. Supporting breastfeeding in emergencies: protecting women's reproductive rights and maternal and infant health. Disasters. 2011;35(4):720-38 https://doi.org/10.1111/j.1467-7717.2011.01239.x PMid:21913933

36. Sohrabizadeh S, Jahangiri K, Jazani RK, Babaie J, Moradian MJ, Rastegarfar B. Women's Challenges and Capabilities in Disasters: A Case Report of the Twin Earthquakes of Eastern Azerbaijan, Iran. PLoS Curr. 2017;9. https://doi.org/10.1371/currents.dis.2cff3d6e9e0c3a 597f873bf29e712370

37. Jahangiri K, Izadkhah Y, Sadighi J. Women's health in natural disasters: a vulnerability analysis. Planet@Risk. 2014;2(2):98-100.

38. Chung RC-Y, Bemak F, Kagawa-Singer M. Gender differences in psychological distress among Southeast Asian refugees. J Nerv Ment Dis. 1998;186(2):112-9.

https://doi.org/10.1097/00005053-19980200000007

39. Holtzman WH, Bornemann TH. Mental health of immigrants and refugees: Hogg Foundation for Mental Health; 1990. Health \& Social Work. 1992;17(4).

40. Camino LA, Krulfeld RM. Reconstructing lives, recapturing meaning: Refugee identity, gender, and culture change. Abingdon, UK: Taylor \& Francis; 1994.

41. Siefert K, Heflin CM, Corcoran ME, Williams DR. Food insufficiency and the physical and mental health of low-income women. Women Health. 2001;32(1-2):159-77. https://doi.org/10.1300/J013v32n01_08 PMid:11459368
42. Baughan DM, White-Baughan J, Pickwell S, Bartlome J, Wong S. Primary care needs of Cambodian refugees. J Fam Pract. 1990;30(5):5658. PMid:2332748

43. Ellis BH, Kia-Keating M, Yusuf SA, Lincoln A, Nur A. Ethical research in refugee communities and the use of community participatory methods. Transcult Psychiatry. 2007;44(3):459-81. https://doi.org/10.1177/1363461507081642 PMid: 17938156

44. Beiser M, Hou F. Language acquisition, unemployment and depressive disorder among Southeast Asian refugees: a 10-year study. Soc Sci Med. 2001;53(10):1321-34. https://doi.org/10.1016/S0277-9536(00)00412-3

45. Miller KE, Weine SM, Ramic A, Brkic N, Bjedic $\mathrm{ZD}$, Smajkic A, et al. The relative contribution of war experiences and exile-related stressors to levels of psychological distress among Bosnian refugees. J $\begin{array}{lll}\text { Trauma } & \text { Stress. } & \text { 2002;15(5):377-87. }\end{array}$ https://doi.org/10.1023/A:1020181124118 PMid: 12392225

46. Guruge S, Roche B, Catallo C. Violence against women: an exploration of the physical and mental health trends among immigrant and refugee women in Canada. Nurs Res Pract. 2012;2012:434592. https://doi.org/10.1155/2012/434592

47. Donnelly TT, Hwang JJ, Este D, Ewashen C, Adair C, Clinton M. If I was going to kill myself, I wouldn't be calling you. I am asking for help: Challenges influencing immigrant and refugee women's mental health. Issues Ment Health Nurs. 2011;32(5):279-90. https://doi.org/10.3109/01612840.2010.550383 PMid:21574842

48. Allotey P. Travelling with "excess baggage": health problems of refugee women in Western Australia. Women Health. 1999;28(1):63-81. https://doi.org/10.1300/J013v28n01_05

49. Bowler I. 'They're not the same as us': midwives' stereotypes of South Asian descent maternity patients. Sociol Health Illn. 1993;15(2):157-78. https://doi.org/10.1111/1467-9566.ep11346882

50. Katbamna S. " Race" and Childbirth. London: Open University Press Buckingham; 2000. PMid:11556369

51. Lipson JG, Weinstein HM, Gladstone EA, Sarnoff RH. Bosnian and Soviet refugees' experiences with health care. West J Nurs Res. 2003;25(7):854-71. https://doi.org/10.1177/0193945903256714 PMid: 14596183

52. Johnson J, Bottorff J, Hilton B, Browne A, Grewell $\mathrm{S}$. Recognizing discrimination in nursing practice: findings from a study of South Asian women and their health care providers in British Columbia. Can Nurse. 2002;98(5):1-6.

53. Anderson JM, Blue C, Holbrook A, Ng M. On chronic illness: immigrant women in Canada's work force--a feminist perspective. Can J Nurs Res. 1993;25(2):7-22. PMid: $\underline{8118765}$

54. Yakushko O, Chronister KM. Immigrant women and counseling: The invisible others. J Couns Dev. 
2005;83(3):292-8. https://doi.org/10.1002/j.15566678.2005.tb00346.x

55. Barnes DM, Harrison C, Heneghan R. Health risk and promotion behaviors in refugee populations. $\mathrm{J}$ Health Care Poor Underserved. 2004;15(3):347-56. https://doi.org/10.1353/hpu.2004.0034 PMid: 15453174

56. Shoeb M, Weinstein HM, Halpern J. Living in religious time and space: Iraqi refugees in Dearborn, Michigan. J Refug Stud. 2007;20(3):441-60. https://doi.org/10.1093/jrs/fem003

57. Belle D, Doucet J. Poverty, inequality, and discrimination as sources of depression among US women. Psychol Women Q. 2003;27(2):101-13. https://doi.org/10.1111/1471-6402.00090

58. McDonough P, Berglund P. Histories of poverty and self-rated health trajectories. J Health Soc Behav. 2003;44(2):198-214.

https://doi.org/10.2307/1519808 PMid: 12866390

59. Chung RC-Y. Psychosocial adjustment of Cambodian refugee women: Implications for mental health counseling. J Ment Health Couns. 2001;23(2):115-26.

60. Riahi A, Hariri N, Nooshinfard F. Study of Health Information Needs and Barriers to Access Among Afghan and Iraqi Immigrants in Iran. J North Khorasan Univ Med Sci. 2016;7(3):597-610. https://doi.org/10.29252/jnkums.7.3.597

61. Chiu L, Morrow M, Ganesan S, Clark N. Spirituality and treatment choices by South and East Asian women with serious mental illness. Transcult Psychiatry. 2005;42(4):630-56. https://doi.org/10.1177/1363461505058920 PMid: 16570521

62. Sirois FM, Gick ML. An investigation of the health beliefs and motivations of complementary medicine clients. Soc Sci Med. 2002;55(6):1025-37. https://doi.org/10.1016/S0277-9536(01)00229-

5Evans D, Norman P. Predicting adolescent pedestrians' road-crossing intentions: an application and extension of the Theory of Planned Behaviour. Health Educ Res. 2003;18(3):267-77. https://doi.org/10.1093/her/cyf023 PMid: 12828229

63. Parker D, Manstead AS, Stradling SG, Reason JT, Baxter JS. Intention to commit driving violations: An application of the theory of planned behavior. J Appl Psychol. 1992;77(1):94-101. https://doi.org/10.1037/0021-9010.77.1.94

64. Diaz EM. Theory of planned behavior and pedestrians' intentions to violate traffic regulations. Transp Res Part F Traffic Psychol Behav. 2002;5(3):169-75. https://doi.org/10.1016/S1369$\underline{8478(02) 00015-3}$

65. Lam LT. Factors associated with parental safe road behaviour as a pedestrian with young children in metropolitan New South Wales, Australia. Accid Anal Prev. 2001;33(2):203-10. https://doi.org/10.1016/S0001-4575(00)00033-6

66. Gilasi H, Moradi A, Gharli ZP, Moazami AG. Knowledge, Attitude and Practice of Pedestrians about Driving Rules in kashan. sjimu. 2013;20(5):37-42. 